\title{
Modern Welfare State and Social Democracy: Interdependence and Policy Importance
}

\author{
Emmanouil Mavrozacharakis, Stylianos Ioannis Tzagkarakis \\ The Centre for Human Rights, Department of Political Science, University of Crete, Rethymno, Greece \\ Email: mavrozaharakis@gmail.com
}

How to cite this paper: Mavrozacharakis, E. and Tzagkarakis, S.I. (2018) Modern Welfare State and Social Democracy: Interdependence and Policy Importance. Open Access Library Journal, 5: e4406. https://doi.org/10.4236/oalib.1104406

Received: February 5, 2018

Accepted: March 12, 2018

Published: March 15, 2018

Copyright $\odot 2018$ by authors and Open Access Library Inc.

This work is licensed under the Creative Commons Attribution International License (CC BY 4.0).

http://creativecommons.org/licenses/by/4.0/

\begin{abstract}
Social democratic parties during the early stages of their development have accepted capitalism and have considered the welfare state as a tool in order to indirectly achieve the goals of social justice and cohesion. In the first half of the 20th century, the welfare state was the basic tool for the implementation of the social democratic ideas, but after the oil crises of the 1970s and more intensively during the last three decades, the deregulation policies led social democracy to seek its identity as an effort which balances between the implementation of embryonic social measures and deregulation policies. At the same time, it is true that the welfare state needs to be transformed in order to meet current challenges (globalization, technological development, population aging), but this targeting does not necessarily mean its complete dismantling as it is the main balancing mechanism of the risks created by the free market economy. This study aims to categorize social democratic parties based on the social policy framework they embrace and to highlight the political deficit that has led to the dismantling of social policy, to the crisis of the state and consequently to European social democracy crisis.
\end{abstract}

\section{Subject Areas}

Politics, Sociology

\section{Keywords}

Social Democracy, Welfare State, Crisis

\section{Introduction}

Scientific analysis on social democracy usually focuses on governmental policies. However, its great transformations have historically made it a very attractive research subject. Given that many theorists dared to predict an end of social democracy, such as Dahrendorf [1] [2] who predicted a premature end, as long as 
he believed that the welfare state has completed its role, then one should consider those elements that have contributed to the sustainability of social democracy to date. It is recalled that about 15 years after Dahrendorf s prediction, European social democracy in the form of the so-called "Third-way" has gone through an unprecedented renaissance and dominated politically most of Western European countries [3]. Even after 15 years, there is again a debate about the crisis and the end of social democracy. All these years, the social democratic parties have been changed in order to regain power in the late 1990s, after the painful years in the opposition. However, by the late 2000s and early 2010, most social democratic parties in Western Europe had returned to the opposition. The exciting question is how social democratic parties manage and process these change processes. The majority of the literature focuses on programmatic change. However, social democracy has a fundamental element in its political and ideological basis, which differentiates it from both the conservative right and the radical left. This is its close relation with the state. Therefore, the theoretical and research interest of this study is concentrated on analyzing this relationship of social democracy with the state under the contemporary conditions of neo-liberal domination.

This relationship is essential in the process of the transformation of social democracy and its constant adaptation to its historical roots. Social democracy, in any case, use the state as a social and regulatory mechanism that may be transformed during specific historical contexts, but is never abandoned. In other words, the regulatory and social pillars of the state (the welfare state) are key elements of legitimizing social democracy. On the basis of diachronic social democratic narratives, the eviction of political power from economy renders economic power uncontrolled, which means that the freedom of workers is reversed to the freedom of sovereignty of economic power over the workers [4]. The liberalization of market forces aims at protecting the economy from problematic political interference. Of course, in the social democratic narratives there is always a distinction between permissible and inadmissible interventions of the state [4]. In any case economic activity is subjected by social democracy under political control through the legal protection of the labor status, the dissolution of feudal forms of work organization, the introduction of participatory processes in the workplace and the introduction of the welfare state. Social policy is the institutional expression of the social idea under conditions of capitalism dominated by social democracy. Social policy is a set of rules and regulations for the protection of workers and in this sense degrades to some extent the power of capital over work.

On the other hand, social policy protects capitalism from the danger of revolution and instability as long as it absorbs the ideas of the social movement, namely, those whose participation in the capitalist system is necessary for the proper functioning of the system. Social concessions serve to maintain capitalism and, in that sense, include conservative motives. This means that social democracy seeks to implement social policies on the one hand, as fulfillment of social demands of workers and on the other hand, as an element of unhindered preservation of capitalism and productive process. In this sense, social democ- 
racy maintains a dual nature as a force that changes capitalism but at the same time sustains it through the state to which a social sign is attached. In a sense, therefore, the promoted compromise by social democracy between market competition and state intervention is perhaps the most effective form of legitimation of developed capitalism [5].

The state undertakes the fulfillment of social justice, something that is not implemented by the market, thus increasing the legitimacy of the capitalist economy through the widening of individual opportunities with particular emphasis on the socially vulnerable, excluded and helpless. Through the integration of welfare measures, the capitalist system appears as an organizational form that firstly minimizes and compensates for individual existential risks, secondly defends the inherent interests of workers, and thirdly, considers the state as a mediating institution that supports workers [5]. The social democratic ideology offers to the vulnerable citizen the right to social protection and services, and at the same time, acknowledges the existence of the capitalist system. This functional sequence constitutes a fundamental element of social democracy that has been preserved over time at its core despite the high cost of the welfare state. If social democracy shares the mantra, namely that is "the state's right and duty to control capitalism" [6], then it can be said that neo-liberalism is definitely an ideology that challenges this opinion. The more detailed theoretical examination of the fundamental element of social democracy, especially under neo-liberal conditions, is the main aim of this study.

Taking into account the abovementioned considerations, this study aims to categorize social democratic parties based on the social policy framework they embrace and to highlight the political deficit that has led to the dismantling of social policy, to the crisis of the state and consequently to the European social democracy crisis. It is true that social policy comprises one of the basic elements for social democratic parties as long as it is the mechanism for the creation of conditions of social equality and justice. However, the transformations that have been conducted during the previous decades have intensified the necessity of transformation of social democratic policies in terms of political implementation rather than of ideological subversion. This paper analyses the necessity of welfare state policies for social democracy but in the reformed and modern socio-economic conditions. In order to achieve this objective the research will begin with the analysis of the limited persuasiveness of the neoliberal theory. It is true that neo-liberal theory has created conditions that assume its policies as a "one-way street" as long as adherents insists that there is no alternative in the modern capitalist system. The following analysis analyze these ideas and considers their limited persuasiveness in order to state that social democratic ideas comprise a viable alternative framework that could offer socially sustainable solutions. The research continues with the analysis of the crisis of social democracy and stateness in order to show the problems and challenges that have been created to social democracy as long as the passive and extensive state is not any long a sustainable choice. Based on this analysis the next chapters study the im- 
portance of reform of capitalism by implementing a new set of social policies that will overcome the previous passive pattern by creating an active framework of welfare state polices.

\section{The Limits of Neoliberalism, the Role of Social Democracy and the Need to Redefine the State}

\subsection{The Limited Persuasiveness of the Neoliberal Theory}

The recent economic crisis coincided with an imaginative public speech, full of unsubstantiated assumptions and fictions, such as the conjecture that it actually comprised the end of neoliberalism as a dominant ideology. In particular, in the left ideological landscape, there was a notion that neoliberalism can be considered dead but still dominant, in the sense that its ideas have been exhausted, but it continues to generate destruction in the form of a living dead [7], because there is a lack of alternatives [8].

This particular position would not have been deprived of a practical basis if there was not a lack of a differentiated logic, far from generalizations, aphorisms and exclusively ideological roots. The differentiation lies in the fact that neoliberalism did not actually fail in political but in economic terms in the sense that it did not yield the expected economic results of both structural and statistical level. In other words, liberalization of the market had more than thirty years to respond to the promise of a scientific economic theory that would make economic growth stronger and more stable, would offer greater opportunities for economic mobility, reduce unemployment and, in general, construct the necessary conditions for achieving prosperity. However, throughout the developed world, the extensive liberalism of the market has failed to achieve its initial objectives. All developing countries, such as China, with high economic development levels, did not follow the neoliberal orders of non-intervention by the state in the market [9] [10]. The over-optimistic projection of market ideology from the neo-liberal thinkers, was at the same time unrecognizable in the sense that it did not take into account that in the two hundred years of the social history of capitalism, the emergence of crises, in social clashes and wars, has been a frequent phenomenon. Therefore, the cultivated expectation by the neoliberal thinkers that the liberalization of markets on an international scale would bring redemption, became dubious [11].

However, despite its economic failure as a theory, the central positions of neoliberalism remain dominant. The political resilience of theory is derived from some theorists, such as Rüstow, in its transcendent foundation beyond any science, as a religious teaching of salvation, which does not defend its arguments in a scientific way, but represents them as sacred principles. According to Rüstow, "neoliberalism is an economic theology that represents a God-demanded order of things in the economy and in society, in which the invisible market hand ensures that the divergent forces return to a continuously harmonious relationship, not to intervene in this process by methods such as state interven- 
tion" [12]. From this perspective, neo-liberalism is the secularization of an irrational theological-stoic perception of harmony. The dominant mistake of this perception is, according to the author, the belief in a natural, automatically fulfilled class of the world and consequently, the refusal of limits of validity of the theory [12]. As Rüstow specifically states [12], "in fact, competition as such does not make the individual moral or incorporate society, since it is directed at personal gain as a driving force". For this reason, "economic competition and the economy in general are under the umbrella of politics to serve society" [12]. At the same theme, Rodrik [9] [13] notes that despite the objections expressed by neo-liberal economists about state functions, successful economic policies have always been backed by the state to promote growth and accelerate structural change. In particular, as it turns out, at the period of the economic crisis, it was national governments that rescued banks, stimulated the financial markets, rescued large businesses, and provided a social safety net [13].

As Legatum Institute suggests [14] [15], Table 1 states such as New Zealand, Norway, Sweden, Denmark, Canada, Australia and Finland, which have a relatively high regulatory role of the state, provide a high level of social welfare, education and individual freedoms as well as they integrate more successfully immigrants and minorities into the real economy and they also display the best economic indicators for 2009-2017.

Consequently, it turns out that social cohesion has a positive impact on the real economy. Most empirical studies show that prosperity and income security are linked to an entire institutional framework, including a variety of legal and regulatory approaches stemming from the degree of state influence on the economy [16] [17]. This is equally true for developed and emerging economies. In particular, earlier IMF surveys [18], the World Bank [19] and several reputable scholars [20] [21] [22], highlight the great importance of the institutional role of the state in economic development. The development of a stable and credible institutional framework at national level facilitates the smooth functioning of society and avoids political and economic conditions [17] [23].

On the other hand, a series of arguments are usually used by the neo-liberal devotees who can be summarized in three categories. The first category focuses on the fact that the large public sector causes tax increases for public funding and this creates distortions and inefficiencies. Hayek [24] argues that the necessary taxation to finance state activity should be subject only to unified principles and not to serve the redistribution of income, that is, the social democratic view of social justice. The second category refers to the fact that public expenditures are inevitably accompanied by the increase in the activities of the state, whose measurable increase in efficiency and productivity is much lower than that of the private sector [25]. In this view, if the state wishes to intervene in the economy, the best way would not be through public spending which would create inflationary pressures but by removing restrictions on trade and the free movement of capital [26]. According to this view the state must be kept away from the economy and intervenes only when certain goods could not be offered by the market. 
Table 1 . The Legatum prosperity index.

\begin{tabular}{|c|c|c|c|c|c|c|c|c|c|c|c|}
\hline $\begin{array}{c}2016 \\
\text { Rank }^{\star}\end{array}$ & $\begin{array}{l}2017 \\
\text { Rank }\end{array}$ & Country & $\begin{array}{c}\text { Economic } \\
\text { quality } \\
\text { 旾 }\end{array}$ & $\begin{array}{c}\text { Business } \\
\text { environment }\end{array}$ & Governance & $\begin{array}{l}\text { Personal } \\
\text { freedom }\end{array}$ & $\begin{array}{l}\text { Social } \\
\text { capital }\end{array}$ & $\begin{array}{c}\text { Safety and } \\
\text { security }\end{array}$ & $\overbrace{}^{\text {Education }}$ & $\stackrel{\text { Health }}{n}$ & $\begin{array}{c}\text { Natural } \\
\text { environment } \\
\varnothing\end{array}$ \\
\hline 2 & 1 & Norway & 8 & 8 & 2 & 8 & 5 & 3 & 4 & 7 & 1 \\
\hline 1 & 2 & New Zealand & 3 & 2 & 3 & 1 & 2 & 23 & 16 & 17 & 13 \\
\hline 3 & 3 & Finland & 14 & 10 & 1 & 9 & 12 & 15 & 3 & 14 & 3 \\
\hline 4 & 4 & Switzerland & 6 & 9 & 5 & 19 & 20 & 8 & 1 & 3 & 16 \\
\hline 8 & 5 & Sweden & 1 & 13 & 4 & 12 & 19 & 13 & 14 & 6 & 8 \\
\hline 7 & 6 & Netherlands & 4 & 14 & 6 & 6 & 11 & 9 & 2 & 8 & 46 \\
\hline 9 & 7 & Denmark & 5 & 11 & 8 & 14 & 4 & 14 & 11 & 21 & 19 \\
\hline 5 & 8 & Canada & 15 & 4 & 9 & 2 & 6 & 24 & 13 & 24 & 18 \\
\hline 6 & 9 & Australia & 20 & 7 & 14 & 15 & 1 & 22 & 5 & 10 & 10 \\
\hline 10 & 10 & United Kingdom & 7 & 5 & 10 & 18 & 16 & 17 & 8 & 19 & 9 \\
\hline 11 & 11 & Germany & 9 & 12 & 12 & 17 & 17 & 16 & 15 & 12 & 12 \\
\hline 13 & 12 & Ireland & 19 & 16 & 13 & 5 & 8 & 10 & 10 & 27 & 27 \\
\hline 14 & 13 & Iceland & 16 & 15 & 11 & 4 & 3 & 2 & 28 & 20 & 21 \\
\hline 12 & 14 & Luxembourg & 11 & 31 & 7 & 3 & 22 & 11 & 30 & 1 & 6 \\
\hline 15 & 15 & Austria & 12 & 18 & 16 & 22 & 15 & 6 & 12 & 5 & 15 \\
\hline 16 & 16 & Belgium & 17 & 17 & 15 & 11 & 25 & 33 & 9 & 11 & 26 \\
\hline 19 & 17 & Singapore & 2 & 6 & 17 & 97 & 26 & 1 & 6 & 2 & 11 \\
\hline 17 & 18 & United States & 10 & 1 & 20 & 28 & 9 & 60 & 7 & 30 & 34 \\
\hline 18 & 19 & France & 25 & 19 & 23 & 25 & 43 & 37 & 19 & 18 & 4 \\
\hline 21 & 20 & Spain & 37 & 33 & 30 & 16 & 29 & 12 & 25 & 16 & 17 \\
\hline 20 & 21 & Slovenia & 29 & 56 & 36 & 21 & 24 & 19 & 22 & 31 & 2 \\
\hline 24 & 22 & Malta & 30 & 55 & 24 & 13 & 7 & 7 & 36 & 23 & 76 \\
\hline 22 & 23 & Japan & 23 & 22 & 18 & 46 & 101 & 4 & 18 & 4 & 43 \\
\hline 23 & 24 & Hong Kong & 18 & 3 & 27 & 43 & 61 & 5 & 21 & 9 & 105 \\
\hline 25 & 25 & Portugal & 35 & 37 & 25 & 10 & 46 & 21 & 63 & 36 & 25 \\
\hline 27 & 26 & Czech Republic & 26 & 25 & 31 & 27 & 73 & 20 & 23 & 26 & 39 \\
\hline 26 & 27 & Estonia & 28 & 28 & 21 & 32 & 60 & 36 & 27 & 57 & 7 \\
\hline 28 & 28 & Uruguay & 52 & 39 & 22 & 7 & 33 & 58 & 72 & 37 & 71 \\
\hline 29 & 29 & Costa Rica & 64 & 43 & 32 & 20 & 35 & 61 & 49 & 32 & 42 \\
\hline 32 & 30 & Italy & 44 & 68 & 46 & 30 & 54 & 25 & 24 & 39 & 65 \\
\hline 33 & 31 & Cyprus & 40 & 40 & 34 & 26 & 36 & 27 & 55 & 41 & 101 \\
\hline 34 & 32 & Poland & 34 & 44 & 37 & 50 & 74 & 18 & 33 & 48 & 47 \\
\hline 31 & 33 & Chile & 48 & 42 & 29 & 40 & 68 & 47 & 37 & 43 & 28 \\
\hline 30 & 34 & Mauritius & 41 & 36 & 26 & 33 & 38 & 44 & 69 & 56 & 62 \\
\hline 36 & 35 & Slovakia & 49 & 51 & 42 & 44 & 65 & 26 & 29 & 45 & 36 \\
\hline
\end{tabular}




\begin{tabular}{|c|c|c|c|c|c|c|c|c|c|c|c|}
\hline \multicolumn{12}{|c|}{ Continued } \\
\hline 35 & 36 & South Korea & 31 & 35 & 39 & 74 & 93 & 29 & 17 & 15 & 90 \\
\hline 37 & 37 & Latvia & 36 & 38 & 40 & 56 & 105 & 41 & 32 & 78 & 5 \\
\hline 40 & 38 & Israel & 33 & 21 & 19 & 94 & 42 & 50 & 20 & 22 & 131 \\
\hline 41 & 39 & $\begin{array}{c}\text { United Arab } \\
\text { Emirates }\end{array}$ & 13 & 24 & 51 & 118 & 27 & 30 & 65 & 25 & 37 \\
\hline 39 & 40 & Panama & 39 & 23 & 60 & 29 & 48 & 72 & 68 & 72 & 41 \\
\hline 42 & 41 & Lithuania & 50 & 52 & 38 & 45 & 135 & 43 & 42 & 67 & 33 \\
\hline 38 & 42 & Malaysia & 24 & 20 & 45 & 120 & 30 & 59 & 31 & 38 & 50 \\
\hline 43 & 43 & Croatia & 66 & 101 & 54 & 42 & 122 & 28 & 34 & 55 & 14 \\
\hline 45 & 44 & $\begin{array}{c}\text { Trinidad } \\
\text { and Tobago }\end{array}$ & 68 & 57 & 49 & 48 & 18 & 81 & 66 & 81 & 40 \\
\hline 47 & 45 & Hungary & 57 & 58 & 56 & 58 & 91 & 34 & 45 & 47 & 94 \\
\hline 50 & 46 & Romania & 60 & 48 & 68 & 51 & 81 & 42 & 52 & 91 & 55 \\
\hline 46 & 47 & Qatar & 22 & 34 & 72 & 101 & 32 & 45 & 96 & 13 & 69 \\
\hline 49 & 48 & Argentina & 81 & 92 & 73 & 23 & 72 & 62 & 60 & 54 & 63 \\
\hline 44 & 49 & Greece & 83 & 72 & 53 & 72 & 89 & 46 & 71 & 42 & 29 \\
\hline 51 & 50 & Suriname & 97 & 138 & 55 & 31 & 66 & 51 & 70 & 49 & 24 \\
\hline 57 & 51 & Bulgaria & 65 & 80 & 71 & 65 & 110 & 40 & 41 & 79 & 35 \\
\hline 48 & 52 & South Africa & 93 & 30 & 35 & 24 & 37 & 124 & 77 & 121 & 48 \\
\hline 56 & 53 & Sri Lanka & 43 & 76 & 57 & 107 & 13 & 75 & 56 & 40 & 58 \\
\hline 52 & 54 & Brazil & 53 & 106 & 77 & 37 & 52 & 88 & 85 & 70 & 23 \\
\hline 55 & 55 & Jamaica & 76 & 32 & 58 & 62 & 31 & 107 & 88 & 62 & 59 \\
\hline 53 & 56 & Macedonia & 92 & 47 & 75 & 76 & 94 & 38 & 44 & 75 & 79 \\
\hline 63 & 57 & $\begin{array}{c}\text { Dominican } \\
\text { Republic }\end{array}$ & 61 & 96 & 85 & 34 & 40 & 101 & 91 & 68 & 20 \\
\hline 66 & 58 & Serbia & 88 & 79 & 67 & 52 & 109 & 31 & 40 & 84 & 107 \\
\hline 61 & 59 & Indonesia & 47 & 61 & 44 & 119 & 10 & 57 & 74 & 101 & 66 \\
\hline 64 & 60 & Peru & 58 & 45 & 69 & 69 & 86 & 96 & 84 & 76 & 32 \\
\hline 65 & 61 & Mexico & 54 & 29 & 82 & 59 & 116 & 122 & 57 & 51 & 52 \\
\hline 67 & 62 & Bahrain & 21 & 41 & 86 & 127 & 59 & 53 & 61 & 28 & 118 \\
\hline
\end{tabular}

The condition for this public activity is, firstly, that the state does not support any monopolistic claim and allows the production of the goods through the market [24]. The state must also provide only goods which are matters of the general interest and do not cover specific and fragmented collective needs. His conception about the limited economic activity of the state is not only contrary to the idea of the socialist planned economy but also to the Keynesian economic policy that is considered as the first step towards a centrally planned economy of central administration [24]. Finally, the third category of arguments is linked to the belief that the public sector is less efficient than the private sector because it 
does not possess the same incentives on the market. Restricting state intervention to the economy and liberalizing private initiative from bureaucracy and stifling administrative arrangements that undermine the incentive for entrepreneurship [27] is based on the idea that the free and uninterrupted operation of the market through is able to ensure the optimal or socially desirable distribution of available means of production, full employment, monetary stability, and economic growth [28].

Consequently, for liberals the free market can substitute the state and become the main regulator of political and economic developments. In particular, Hayek advocated the liberalization and deregulation of financial transactions not only within the national borders of a country but internationally by the privatization of state-owned enterprises, the reduction of state spending, and the creation of a powerful state that would protect institutionally the legal operation of the market without interfering [29].

On the contrary, state supporters and social democrats usually insist that the state offers useful services that improve both the individual position as well as the position of the businesses. A public sector with high levels of public spending can provide sufficient levels of infrastructure, a well-trained workforce and an effective health care service, factors that contribute to the increase of the productivity of an economy. Financing these costs requires high taxation. Therefore, the negative effects of high taxation are offset by the positive effects of higher public spending. In addition to spending and taxes, regulating state interventions (institutions) also play an important role in economic development. It also appears that countries with a large public sector have much better institutional quality, better education and social protection systems and greater opportunities for innovation.

It is true that there are four economic development models followed by the different countries in the developed world: the Anglo-Saxon, the Nordic, the Continental and the Mediterranean. As it is clear in Figure 1, Sapir [30] classifies these basic models of analysis based on the criteria of social justice (equity) and economic efficiency.

From this typology, it appears that the Nordic model, which has a high level of public intervention and institutional development while is considered to be a model for the implementation of non-irrevocable social-democratic policies, is characterized by high economic efficiency and social equality. However, the Mediterranean model has low levels of efficiency and equality due to a lack of institutional development and public effectiveness.

As it can be easily seen from the international indicators of economic competitiveness (Table 2), countries with developed public services and institutional maturity such as Germany, France, the Netherlands, New Zealand, Canada, Japan and all the countries of the so-called "social democratic model" (Sweden, Finland, Norway, Denmark) are among the 20 most competitive economies in the world. Despite the fact that countries in Northern Europe and Scandinavia 
Table 2. The global competitiveness index 2017-2018 [31].

\begin{tabular}{|c|c|c|c|c|c|c|c|c|}
\hline \multicolumn{9}{|c|}{ Subindexes } \\
\hline \multirow[t]{2}{*}{ Economy } & \multicolumn{2}{|c|}{$\begin{array}{l}\text { Overall } \\
\text { index }\end{array}$} & \multicolumn{2}{|c|}{$\begin{array}{l}\text { Basic } \\
\text { requirements }\end{array}$} & \multicolumn{2}{|c|}{$\begin{array}{l}\text { Efficiency } \\
\text { enhancers }\end{array}$} & \multicolumn{2}{|c|}{$\begin{array}{c}\text { Innovation and } \\
\text { sophistication } \\
\text { factors }\end{array}$} \\
\hline & Rank & Score & Rank & Score & Rank & Score & Rank & Score \\
\hline Switzerland & 1 & 5.86 & 1 & 6.39 & 3 & 5.65 & 1 & 5.86 \\
\hline United States & 2 & 5.85 & 25 & 5.54 & 1 & 6.01 & 2 & 5.80 \\
\hline Singapore & 3 & 5.71 & 2 & 6.34 & 2 & 5.72 & 12 & 5.25 \\
\hline Netherlands & 4 & 5.66 & 4 & 6.24 & 8 & 5.46 & 4 & 5.62 \\
\hline Germany & 5 & 5.65 & 11 & 5.97 & 6 & 5.53 & 3 & 5.65 \\
\hline Hong Kong SAR & 6 & 5.53 & 3 & 6.26 & 4 & 5.58 & 18 & 4.96 \\
\hline Sweden & 7 & 5.52 & 8 & 6.00 & 12 & 5.30 & 5 & 5.57 \\
\hline United Kingdom & 8 & 5.51 & 23 & 5.65 & 5 & 5.55 & 9 & 5.34 \\
\hline Japan & 9 & 5.49 & 21 & 5.66 & 10 & 5.39 & 6 & 5.55 \\
\hline Finland & 10 & 5.49 & 9 & 5.98 & 11 & 5.30 & 8 & 5.48 \\
\hline Norway & 11 & 5.40 & 6 & 6.02 & 14 & 5.29 & 13 & 5.19 \\
\hline Denmark & 12 & 5.39 & 13 & 5.90 & 15 & 5.26 & 11 & 5.28 \\
\hline New Zealand & 13 & 5.37 & 5 & 6.05 & 9 & 5.43 & 25 & 4.81 \\
\hline Canada & 14 & 5.35 & 17 & 5.72 & 7 & 5.52 & 24 & 4.82 \\
\hline Taiwan, China & 15 & 5.33 & 15 & 5.84 & 16 & 5.25 & 15 & 5.12 \\
\hline Israel & 16 & 5.31 & 28 & 5.48 & 19 & 5.12 & 7 & 5.53 \\
\hline $\begin{array}{c}\text { United } \\
\text { Arab Emirates }\end{array}$ & 17 & 5.30 & 7 & 6.02 & 17 & 5.23 & 20 & 4.93 \\
\hline Austria & 18 & 5.25 & 19 & 5.70 & 22 & 5.03 & 10 & 5.30 \\
\hline Luxembourg & 19 & 5.23 & 10 & 5.98 & 23 & 5.01 & 16 & 5.11 \\
\hline Belgium & 20 & 5.23 & 27 & 5.48 & 18 & 5.15 & 14 & 5.18 \\
\hline Australia & 21 & 5.19 & 18 & 5.70 & 13 & 5.29 & 27 & 4.68 \\
\hline France & 22 & 5.18 & 26 & 5.54 & 20 & 5.10 & 17 & 5.07 \\
\hline Malaysia & 23 & 5.17 & 24 & 5.55 & 24 & 4.94 & 21 & 4.91 \\
\hline Ireland & 24 & 5.16 & 20 & 5.68 & 21 & 5.09 & 19 & 4.93 \\
\hline Qatar & 25 & 5.11 & 12 & 5.91 & 25 & 4.94 & 22 & 4.85 \\
\hline Korea, Rep. & 26 & 5.07 & 16 & 5.77 & 26 & 4.93 & 23 & 4.85 \\
\hline China & 27 & 5.00 & 31 & 5.32 & 28 & 4.88 & 29 & 4.33 \\
\hline Iceland & 28 & 4.99 & 14 & 5.88 & 32 & 4.77 & 26 & 4.77 \\
\hline Estonia & 29 & 4.85 & 22 & 5.66 & 27 & 4.92 & 35 & 4.20 \\
\hline Saudi Arabia & 30 & 4.83 & 32 & 5.28 & 33 & 4.69 & 40 & 4.12 \\
\hline
\end{tabular}




\section{Continued}

\begin{tabular}{|c|c|c|c|c|c|c|c|c|}
\hline Czech Republic & 31 & 4.77 & 30 & 5.35 & 29 & 4.86 & 32 & 4.24 \\
\hline Thailand & 32 & 4.72 & 41 & 5.06 & 35 & 4.62 & 47 & 3.92 \\
\hline Chile & 33 & 4.71 & 36 & 5.13 & 31 & 4.83 & 50 & 3.86 \\
\hline Spain & 34 & 4.70 & 33 & 5.15 & 30 & 4.84 & 38 & 4.17 \\
\hline Azerbaijan & 35 & 4.69 & 47 & 4.93 & 46 & 4.44 & 33 & 4.22 \\
\hline Indonesia & 36 & 4.68 & 46 & 4.98 & 41 & 4.52 & 31 & 4.29 \\
\hline Malta & 37 & 4.65 & 29 & 5.41 & 37 & 4.61 & 34 & 4.20 \\
\hline Russian Federation & 38 & 4.64 & 48 & 4.92 & 38 & 4.59 & 57 & 3.76 \\
\hline Poland & 39 & 4.59 & 45 & 4.99 & 34 & 4.65 & 59 & 3.75 \\
\hline India & 40 & 4.59 & 63 & 4.68 & 42 & 4.47 & 30 & 4.29 \\
\hline Lithuania & 41 & 4.58 & 34 & 5.15 & 40 & 4.57 & 44 & 4.04 \\
\hline Portugal & 42 & 4.57 & 39 & 5.12 & 39 & 4.58 & 36 & 4.18 \\
\hline Italy & 43 & 4.54 & 51 & 4.88 & 43 & 4.46 & 28 & 4.45 \\
\hline Bahrain & 44 & 4.54 & 40 & 5.08 & 36 & 4.62 & 43 & 4.05 \\
\hline Mauritius & 45 & 4.52 & 44 & 5.01 & 59 & 4.28 & 46 & 3.93 \\
\hline Brunei Darussalam & 46 & 4.52 & 42 & 5.05 & 74 & 4.06 & 88 & 3.46 \\
\hline Costa Rica & 47 & 4.50 & 53 & 4.82 & 48 & 4.43 & 42 & 4.08 \\
\hline Slovenia & 48 & 4.48 & 35 & 5.14 & 53 & 4.39 & 37 & 4.18 \\
\hline Bulgaria & 49 & 4.46 & 59 & 4.77 & 50 & 4.40 & 73 & 3.57 \\
\hline Panama & 50 & 4.44 & 37 & 5.12 & 57 & 4.29 & 48 & 3.89 \\
\hline Mexico & 51 & 4.44 & 68 & 4.59 & 47 & 4.43 & 51 & 3.84 \\
\hline Kuwait & 52 & 4.43 & 50 & 4.88 & 73 & 4.07 & 86 & 3.47 \\
\hline Turkey & 53 & 4.42 & 60 & 4.75 & 51 & 4.40 & 66 & 3.65 \\
\hline Latvia & 54 & 4.40 & 43 & 5.01 & 49 & 4.40 & 68 & 3.65 \\
\hline Vietnam & 55 & 4.36 & 75 & 4.52 & 62 & 4.24 & 84 & 3.49 \\
\hline Philippines & 56 & 4.35 & 67 & 4.60 & 61 & 4.27 & 61 & 3.72 \\
\hline Kazakhstan & 57 & 4.35 & 69 & 4.59 & 56 & 4.32 & 95 & 3.39 \\
\hline Rwanda & 58 & 4.35 & 65 & 4.62 & 84 & 3.95 & 49 & 3.87 \\
\hline Slovak Republic & 59 & 4.33 & 52 & 4.83 & 44 & 4.46 & 56 & 3.76 \\
\hline Hungary & 60 & 4.33 & 64 & 4.65 & 45 & 4.44 & 79 & 3.52 \\
\hline South Africa & 61 & 4.32 & 92 & 4.28 & 52 & 4.39 & 39 & 4.14 \\
\hline Oman & 62 & 4.31 & 38 & 5.12 & 66 & 4.19 & 70 & 3.61 \\
\hline Botswana & 63 & 4.30 & 61 & 4.73 & 89 & 3.87 & 91 & 3.44 \\
\hline Cyprus & 64 & 4.30 & 49 & 4.92 & 55 & 4.36 & 55 & 3.79 \\
\hline
\end{tabular}




\section{EFFICIENCY}

\begin{tabular}{|c|c|c|}
\hline \multirow{3}{*}{$\begin{array}{ll}己 \\
\underset{\Xi}{\partial} \text { High } \\
\text { Low }\end{array}$} & Low & High \\
\hline & Continental & Nordic \\
\hline & Mediterranean & Anglo-Saxon \\
\hline
\end{tabular}

Figure 1. A typology of European economic development models.

still have a large public sector, it is interesting that they are among the most competitive economies in the world.

Economically and financially, market economies need strong state institutions for achieving macroeconomic and fiscal stability as well as for the stability of the economy, legal security of transactions, smooth functioning of the market and social cohesion. The role of a credible public institutional framework for the development of general investment and development conditions through appropriate incentives that generate trust, transaction security and efficiency, is therefore crucial. In this context, the role of the state in properly regulating the labor market as well as the financial markets is clearly necessary.

However, the pursuit of the neo-liberal perception after the 1980s, along with the social-democratic compromise of the Third Way, prevented the development of an appropriate institutional building at both national and international level for the proper political regulation of the economy. Instead, economic reforms have primarily focused on privatizing public goods as well as deregulating and liberalizing the markets. The economic policy of that era was expressed by the term "Washington Consensus". In essence, this was a ten-point agenda developed by Williamson [32] mainly constructed for Latin American countries, in order to overcome over-indebtedness and supposedly stimulate growth [17]. The proposed measures focused on reducing state intervention in the economy, fiscal discipline, opening markets for trade and foreign direct investment, restructuring public spending, liberalizing political interest rates, liberalizing trade, deregulating intensifying privatization, reforming taxation, increasing monetary competitiveness and safeguarding property rights [17].

Although this agenda was originally designed for the Latin American countries, it soon became a generalized implementation model for international institutions such as the IMF and the World Bank, as well as Reagan governments in the USA and Thatcher/Blair in the United Kingdom. Because the agenda was influenced by economic liberalism and focused on deregulation, privatization and liberalization of the markets, it was called "neo-liberal". Just a few years after its first implementation, the neo-liberal agenda was severely criticized by the fact that the countries in which it was applied (Mexico, Argentina, Brazil, several Asian countries) instead of reducing public debt, were even more indebted, while their economies were collapsing. This neo-liberal agenda can therefore be regarded as imperfect, with a dominant weakness; that it seeks to liberalize and deregulate the markets unilaterally, without framing this operation with the re- 
quisite institutional security that only the state can provide and thus exposes the countries in severe crisis risks. At the same time, with its regulatory gap, the neo-liberal agenda also includes an institutional gap in social terms, since reforms aimed at liberalizing market forces are not combined with the required compensatory social measures, such as minimal social security, wider distribution of income and a minimum level of equal opportunities. In particular, the social vacuum of neo-liberal agenda has led to a process of de-legitimization. The reasons for the failure of the Washington consensus are confirmed, as mentioned above, in a number of recent studies that examine the importance of the state and its institutional framework for the long-term development of the economy.

Particularly, Hall and Jones [20] have found a positive correlation between per capita income and the quality of social infrastructure, which is determined by the degree of legal certainty, the quality of bureaucracy, the corruption susceptibility, the risk of investment loss and the level of liberation of the respective economy. In any case, the economic affairs of neoliberalism [10] are not verified, such as the specific one which suggested that the period of incomparable macroeconomic stability would last forever. Also, the assumption that the prices determined by the financial markets are the most accurate assessment of investment values and the assumption of the reduction of individual economic behavior as a rational macroeconomic policy criterion, have not been verified either. Neo-liberal ideas also do not seem to have the necessary validity, namely those which insist that upgrading policies for the affluent will lead to upgrading the socially vulnerable, and that state functions and initiatives can be more effective if privatized.

\subsection{The Practical Social Significance of the State and the Role of Social Democracy}

Social democracy from a purely practical point of view expresses a kind of empirical stateness that is based on functional aspects of the state [33] [34], such as security provision, utilization and redistribution of resources and provision of public goods and services (prosperity). In addition, however, the state in the hands of social democracy also provides an additional and not at all benevolent good, that of stability and social peace, which directly legitimates the monopoly of violence as "the basic test of the existence of a state" [35].

As it is empirically evidenced in an earlier publication by Huber and Stephens [36] (Table 3), social democratic states are characterized by their generosity and redistributive function (see Table 1, columns 1, 2,7) while the Christian democratic states show high generosity but are less redistributive. The liberal welfare states are still less generous and show little redistribution. Social democratic states seek universal coverage for a wide range of social risks through the combination of basic security and income protection with comparatively generous benefits for low-income people as well as the public provision of a large part of free or subsidized services (columns 5 and 7). 
Table 3. Characteristics of welfare state and production regime.

\begin{tabular}{|c|c|c|c|c|c|c|c|c|c|}
\hline \multicolumn{2}{|l|}{1} & 2 & 3 & 4 & 5 & 6 & 7 & 8 & 9 \\
\hline \multicolumn{2}{|c|}{$\begin{array}{l}\text { Post-Tax } \\
\text { \& transfer } \\
\text { Gini }\end{array}$} & $\begin{array}{l}\text { Reduction in } \\
\text { Gini due to } \\
\text { taxes \& transfers }\end{array}$ & $\begin{array}{c}\text { Wage } \\
\text { dispersion }\end{array}$ & $\begin{array}{c}\text { Literacy } \\
\text { score } \\
\text { 5th percentile }\end{array}$ & $\begin{array}{c}\text { Public } \\
\text { employment }\end{array}$ & $\begin{array}{c}\text { Female } \\
\text { labor force } \\
\text { participation }\end{array}$ & $\begin{array}{l}\text { Decommodification } \\
\text { index }\end{array}$ & $\begin{array}{l}\text { Total } \\
\text { taxes }\end{array}$ & $\begin{array}{c}\text { Bargaining } \\
\text { centralization }\end{array}$ \\
\hline \multicolumn{10}{|c|}{ Social democratic welfare states } \\
\hline Sweden & 20 & 43 & 2.1 & 216 & 20 & 80 & 39 & 63 & 0.31 \\
\hline Norway & 22 & 29 & 2.0 & 207 & 15 & 71 & 38 & 56 & 0.58 \\
\hline Denmark & 21 & 38 & 2.2 & 213 & 18 & 78 & 38 & 56 & 0.37 \\
\hline Finland & 19 & 34 & 2.4 & 195 & 9 & 73 & 29 & 51 & 0.44 \\
\hline Mean & 21 & 36 & 2.2 & 208 & 16 & 76 & 36 & 57 & 0.42 \\
\hline \multicolumn{10}{|c|}{ Christian democratic welfare states } \\
\hline Austria & 21 & & & & 4 & 55 & 31 & 47 & 0.44 \\
\hline Belgium & 21 & 40 & 2.3 & 161 & 6 & 52 & 32 & 49 & 0.29 \\
\hline Netherlands & $2 ð$ & $2 ð$ & 2.ð & 202 & 4 & 53 & 32 & 52 & 0.35 \\
\hline Germany & 30 & 23 & 2.5 & 208 & 4 & 57 & 28 & 43 & 0.32 \\
\hline France & 32 & 24 & 3.3 & & 7 & 58 & 28 & 47 & 0.10 \\
\hline Italy & 29 & 12 & 2.4 & & 5 & $4 ð$ & 24 & 42 & 0.14 \\
\hline Switzerland & 31 & 11 & 2.7 & 150 & 5 & д0 & 30 & 34 & 0.25 \\
\hline Mean & 27 & 23 & 2.6 & 180 & 5 & 54 & 29 & 45 & 0.27 \\
\hline \multicolumn{10}{|c|}{ Liberal welfare states } \\
\hline Australia & 29 & 24 & 2.9 & 146 & 7 & 63 & 13 & 35 & 0.47 \\
\hline New Zealand & & & & 157 & & 63 & 17 & & \\
\hline Canada & 28 & 26 & 4.2 & 145 & 7 & 75 & 22 & 42 & 0.07 \\
\hline Ireland & 32 & 32 & & 145 & & 69 & 23 & 39 & \\
\hline UK & 33 & 23 & 3.3 & 145 & 8 & 65 & 23 & 40 & 0.12 \\
\hline USA & 33 & 18 & 4.9 & 133 & 5 & 69 & 14 & 32 & 0.07 \\
\hline Mean & 31 & 25 & 3.8 & 145 & 7 & 67 & 19 & 38 & 0.18 \\
\hline
\end{tabular}

As Huber and Stephens [36] note "basic security is provided through universal flat-rate benefits, and income security through the addition of earnings-related benefits. In the area of social services, social democratic welfare states provide not only health care but also care for children and the elderly, rehabilitative services for the disabled, and retraining and relocation assistance for those losing their jobs or having been separated from the labour market for a while (see column 5). Neither Christian democratic nor liberal welfare states provide any of these kinds of services; at best, they finance a limited array of privately provided services for the needy. These services, along with generous child allowances, make the social democratic welfare states women-friendly and encourage female labour force participation (see column 6). On the financing 
side of the welfare state, separate taxation makes female labour force participation financially attractive. Social services and basic transfer benefits are typically financed by general revenue, whereas earnings related benefits are financed by earnings-related social security contributions. The total tax burden necessary to finance the generous transfers and services is high (see column 8)".

In this regard, social democracy has applied the aspect of public welfare and social policy as a flexible element of the state which is quantitatively and qualitatively adapted to historical circumstances. Therefore, the social democratic version of the state uses social normalization through social policy and through the provision of public goods and services not only as an element of social prosperity but also as an element of stability.

Although the existence of the state does not presuppose the dimension of social prosperity, in the social democratic form of the state the provision of public goods and services and the construction of social prosperity are necessary choices of state activity. That is why the social democratic welfare state was established after the Second World War and in its pure form until the 1980's has fulfilled three basic functions: the redistribution of wealth through taxation, the security of the individual against risks through social security and transfers and the provision of goods and services to all people [37].

As a result, state has gained a very high degree of control, which often led to criticism. As the neo-liberal economic model prevailed, the role and the responsibilities of the state were redefined. Since then, the most important task of the state has been to ensure competitiveness. The provision of goods and services has been subjected to market criteria or has been fully transferred to private companies in order to make them more effective and customer-oriented, a promise that has never been implemented. Basic goods and services have become more expensive and they are often no longer sufficiently available at national level.

Therefore, the state is not a neutral factor, representing general interests, but it reflects the social association of different forces-interests. In defining the goods of the classical economy, public goods are characterized by "non-exclusivity". Since exclusivity is socially negotiable, the agreement on what is publicly available is decided on a political level. Even Adam Smith [38] had insisted that the state must provide certain public goods because they are not marketable such as education.

Under social democratic governance, many policy areas such as energy, water supply, public transportation, social housing, public media, health care and education were delivered to the welfare state through political decisions. This was implemented under the prerequisite that these goods are available to all. However, through political decisions these goods are currently delivered, under the pressure of neo-liberalism, to the market. In this duality between market and state, social democracy focuses on the state's role while neo-liberalism on the market side. It is precisely therefore from this distinction that social democracy derives its viability. 
At this point, however, it is important to refer to the definition of democracy which refers to the existence of certain fundamental rights linked with the rule of law. As far as the fulfillment of these rights is concerned, there is also an aspect of the provision of public goods such as education [39]. In particular, education is important since it allows the implementation and fulfillment of civil rights [40]. As regards the dimension of security and stability, the fulfillment of this public duty is a prerequisite for any form of development. We can therefore conclude that democratic principles and processes can only be developed in a safe and stable environment that is pursued by the social dimension of the state. Consequently, it is of fundamental importance that the preservation of democracy as a precondition of the monopoly of power is achieved only when the protection of rights and freedoms is guaranteed at national level [41] [42]. So, in essence, social democracy expresses a quintessence of the bourgeois state that can only be removed by neo-liberalism through its neutralization. The scope of legislation is in line with this dimension. It may be argued that a developed system of rules is a prerequisite for the formulation of fundamental rights and, furthermore, is the basis for the emergence of a constitutional state.

As regards the relationship between democracy and the raising of resources, this is particularly important for the delivery of public goods. For instance, the right to education is not able to be guaranteed if funds are not available. Finally, a functional bureaucracy is necessary for the "proper application of the legal framework" [41]. Only when the administrative structures are effective can the rule of law be preserved.

This brief overview of the relationship between the different dimensions of the state and democracy demonstrates the importance of an effective state for achieving socio-economic development but also for the imposition and preservation of democratic processes. The state that social democracy defends, however, should not be considered as a sufficient condition in itself, because the concept of state power often serves as the basis of an authoritarian regime. Consequently, only the state is linked to both the social and the executive aspect of democracy, with specific demands on the state, such as the application of legislation, the separation of powers or even the transparency of democracy [43]. At this level the demarcation of research about social democracy lies. Research should focus on the extent to which social democracy in the future can defend itself without defending doctrinal and developmental automation to defend a state that will facilitate the viability of democratic processes, both material, economic and political.

From a practical point of view, ensuring a certain level of living is to a large extent linked to the delivery of public policies based on the public interest and the public good [44]. The public good is “... the good from which, once it is in the community, each individual can at the same time obtain service of equal quantity and of the same quality as the whole provided by the good" [45]. Ultimately, the definition of the public good and its regulation (economic or legislative) typologically and morphologically belongs to the governmental policy. So- 
cial democracy, therefore, with its strong perception of the regulatory role of the state and public policies, in fact defense the common good, which contributes to improvement of the general level of prosperity. Of course, the state and public policies are articulated on the hierarchical bureaucratic model of administration, whose basic characteristics are the importance of the rule of law, the rigor of administrative procedures and the importance of public interest [44].

Only through public policies can social justice be provided. As noted in various empirical studies, citizens consider equal education opportunities as the most important public policy. Policies on social security are also very important. Moreover, it is noteworthy from a practical point of view that major legislative and policy initiatives at national and European level have made a significant contribution to the promotion of gender equality in employment. Legislative interventions by the state have made significant progress in achieving equal political rights, which have had a significant impact on the establishment of gender equality and in other spheres of women's life, fulfilling in this way the fundamental values of freedom and equality.

\subsection{The Crisis of Social Democracy}

It is true that neoliberalism has dominated and continues to monopolize the political narratives of the majority of political parties, including social democracy. Neo-liberalism was now transformed into a political venture that seeks a political basis for legitimacy in societies, especially in the middle socio-economic groups [46]. Moreover, with the consensus of these socio-economic groups, neo-liberal parties prevailed in the core of Western Europe without great resistance, which embraced the undertaking of fiscal stability, bank rescue and austerity [17]. The neo-liberal ideology affected Western societies in adopting fiscal stability as a one-way street. At the same time it affected also the progressive narratives and especially the social democratic one, on a common path of decline.

An example of the above statement could be the variations of neoliberalism associated with the Third Way of social democracy. These variants have attempted through a more active role of the national state and by accompanying social measures, in order to obtain broader consensus on the deregulation of the markets [47]. In contrast to post-war social democracy, which was limited to the obsession with the national state and its intervening functions, the new social democracy considered the state as the Achilles heel of its narrative that prevented the adaptation to the conditions of globalization and the expansion of privatization. The new approach raised the question of economic inefficiency of the state and the threat of individual liberties and rights from both the economy and the state itself. As Gauchet [48] notes, since 1970, it has challenged the social democratic compromise, which was implemented after the Second World War and was associated with a profound transformation. Its key tool was the state's intervention in the economy on the basis of the Keynesian vision, while consolidating the structures of the welfare state and social protection, strengthening the executive power and mitigating class conflicts. This has also ensured democracy, 
which has managed to reduce the totalitarian challenges, especially after the Second World War, through the institutionalization of the compromise between "capital and labor" and between "democracy and totalitarianism". Today we can clearly assume that the main characteristics of this kind of compromise have been significantly transformed.

As a result, social democracy abandoned its socially-compensatory reform strategy in the context of capitalist dynamics and accepted the liberal model of globalization, based on the assumption that complete liberalization of the markets could be combined with the implementation of sociopolitical policies [49]. In the name of linear economic order promotion, social democracy has removed from the essence of its identity by moving from the model of Rhine capitalism to an Anglo-Saxon economic model with a reversed logic [49].

The new financial capitalism that prevailed is characterized by a relentless expansion of market into geographic and social fields that were not yet embedded in capitalism. This is automatically linked to the deregulation of specific rules that restrict the market [49]. In the midst of the global economic crisis, the inadequacy of unrestricted liberty of the markets, both as an economic and an ideological model [50], emerged among others. However, along with the inadequacy of the markets, the Third Way crisis followed, which was implemented by the New Social Democracy.

Today, social democracy is in danger of losing its hegemonic position within the progressive political spectrum because it has lost the tradition of radical reformism, which historically was characterized by great political, social and economic advantages. As a result, social democratic parties are not able to reap the diffused social anger that is reproduced during the crisis. Shattered societies turn to the right and left-wing populist parties that have the largest inflows of new members and voters in the post-war period. From the point of view of the extreme right, the adoption of the harsh anti-capitalist criticism, which was once prized by the left [51], seems to be fruitful.

On the contrary, the European Social Democracy and the greater reformist left remain deeply divided, and there has never been such a great deal of uncertainty about criticism of capitalism and its long-term goals. It is a fact that the moral and intellectual weakness of progressive space explains the prevalence of neoliberalism as a modern political direction despite all the economic disasters it has brought.

It turns out that in countries that social democrats and socialists managed to win the elections during the crisis, they played the unrivaled role of a "mere manager", acting under the close control of the European Council, the European Central Bank and the International Monetary Fund. Whether in the government or in opposition, the severe economic crisis found the European center-left in great unease, with no plan and vision with viable alternatives. As a result, improvisations and rough maneuvers have prevailed to a certain extent in the face of the fast exploitation of financial market dangers, the increasing anger of voters and the growing fear of the future. 
Therefore, it is not unreasonable to note that the exchange of strong traditional principles and values with unclear visions of the center undermines unity, and ultimately even the aspirations of social democracy leading to a profound ideological, political and organizational crisis. The constant mutation of social democracy was accompanied by a process of historical power dynamics, partly causing large and widespread shocks.

\subsection{The Crisis of Stateness and the New Role of Social Democracy}

The opening of the New Social Democracy to neo-liberalism was accompanied by the abandonment of the state as a central tool for public policy and its regulatory capabilities towards market functions [52] [53]. Consequently, during the crisis, the state was confined to certain distinct functions that were common to both social democratic and conservative governments. It is noted that some theoretical approaches refer to the phenomenon of "Lemon Socialism" [54], on which social democracy not only participated in the rationale of expanding the markets but pioneered it. The term "Lemon Socialism" may be considered to have a deceptive character that refers to governments that, in the face of the risk of widespread economic destabilization, support the private sector and lead the way in rescuing companies threatened by an imminent collapse [55].

The most frequent governmental interventions include capital injections, bailouts, and some governmental control over companies, governmental involvement in corporate decision-making, and nationalization. This strategy has been translated into practice by socializing the losses produced by various businesses or banks after decades of privatization of their profits [56].

If the future role of social democracy for the state is to socialize the losses of companies and to privatize their profits, then the social character of public policies is questioned, on the one hand, and the possibility of universalization of the social dimension of the state as such. It turns out that globalization is clearly problematic in its neo-liberal version, nevertheless the internationalization of global economic transactions and political processes is so advanced that it becomes unlikely to return to the "prosperous old days" of the Keynesian Fordism of the 1970s. Consequently, the crisis does not particularly facilitate social democracy in its ideological and organizational renewal. In any case, however, there is a clear need to investigate and overcome the crisis of so-called "stateness" in the sense of the existence of a tangled interconnection of state, interest groups, trade unions and the exhaustion of public resources which leads to the over-indebtedness in order to meet reproductive and legitimate policy needs.

Indeed, contrary to the interwar period, where particular emphasis was given on the creation of state-independent economic structures, social democracy of the post-war period was limited to the reform of the state and omitted direct concern with the population and its self-serving forces. This has led to an obsession with the national state, which, as a consequence of globalization and privatization, proved to be the Achilles heel of social democracy. Moreover, this per- 
sistence produced a "pre-social democracy" with the importance of individual freedoms and rights, which can be threatened at all times by both the economy and the state. Therefore, the question that arises today is the extent to which social democracy can restore or reconstruct important state functions in conjunction with a model of the market that is in line with the principles of solidarity, social justice and at the same time does not restrict economic dynamics and stability.

The new center-left must promote three difficult issues at the same time. Firstly, it should promote growth, secondly, ensure that this development integrates society, that is to say, the vulnerable social groups, and thirdly, reduce budget deficits [57]. It is obvious that social democracy needs to be reconnected with the Keynesian agenda, especially in terms of job creation and economic growth, support the welfare state and improve financial market regulation. However, it has also to overcome some serious issues. On the one hand, it should abandon the so-called "Keynesianism of the bazaar", which neglects budgetary discipline and is linked with demand stimulation through uncontrolled state spending, ignoring the supply side and, on the other hand, promote and improve the tax and expense philosophy [57]. In 1991, for instance, Sweden reduced its income and capital tax with a very positive impact on both innovation and growth [57]. At the same time, the indicators of social cohesion have remained relatively high and the benefits of the welfare state have remained universal. Therefore, the question is: How can relations between the state and market be restructured in order to maintain and strengthen the welfare state and social cohesion within an active state? In other words, how can a new socioeconomic example of a social democratic agenda for the 21st century be established, guaranteeing social progress without subduing the economic objective of continuous growth and without being weakened by fiscal derailment? This question is directly related to the prevailing trend of secular stagnation, which places obvious limits on the social surpluses required for the pursuit of balancing social policies while stabilizing the distortions created by markets [58].

The redefinition of the relationship between state and market can be better enhanced through a new social democratic economic and social policy. The terms and conditions of this policy are: the maintenance of the welfare state and social cohesion, the construction of a new active state and the development of a new socioeconomic model that will differentiate social progress from simple economic growth [59]. As the social democratic proposal of power was more or less assimilated by political systems dominated by economic lobbies (post-democracy) and, moreover, the economy gained a dominant position than the policy, while has consistently defined developments throughout the crisis, the question that arises is to what extent there is a possibility of formulating a social democratic prospective governmental proposal that will bring the state back to its central role, even in diversified and more effective functions [60]. In this paper, there will be an attempt to outline a new reform framework for social democracy by mainly focusing on a new role for the state. 


\section{The New Policies for the Reformation of Capitalism}

\subsection{The Welfare State as the Core of the New Policy}

It turns out that the new social democracy currently acts under a completely defensive attitude towards the power of neo-liberalism. However, European social democracy should potentially lead a capitalist reform movement, disconnect with the "social democracy of fear" and define a new role of the welfare state at national and European level [62]. This will benefit European societies from finding sustainable solutions without disrupting social cohesion and the rights that comprise a significant prerequisite.

This will require a new historical compromise between capital and labor that would allow the creation and development of such a welfare state. Undoubtedly, those elements that once constituted the so-called "organized capitalism" or "Rhine capitalism" under the "Keynsian consensus", have been changed even though they consisted the hidden ideal of European social democracy. In the current liberated, disorganized and deregulated capitalism the elites ignore all compromises. The main fear of the lower socioeconomic groups is a possible further social reduction, after the elites carried on them the cost of the recent economic disruption that led to the fourth Great Depression in the history of capitalism. This particular fear and the threat of the subsequent social democratic compromises lead to the "socialist austerity experiments", as they emerged in Greece, Italy and Portugal, during the crisis, but also earlier in Germany during Schröder era or in England during the period of Blair's Third Way. In this context, new radical views are needed for the construction of a modern social democracy. Such a view was expressed by Judt [61] who does not believe in common recipes and synchronized international solutions to all problems on a global scale. Judt praises the welfare state within old Europe rather than the United States, as it can be the ideal model of the future welfare for societies. There is no tradition of social democracy in the US so Judt calls on European Social Democracy to recall its strong roots. These lie in the transformation of capitalism, in which social democracy in Europe had played a leading role. A transformation associated with the consolidation of the welfare state, the intervening state, the extensive public goods and services sector as well as the domestication and regulation of capitalism, could counterbalance the negative social consequences and lead to a viable social future [62].

This new approach will be based on the tradition of the democratic left, which has criticized the Leninist way towards socialism. But this does not mean that without much hesitation European social democracy must abandon its rich subversive heritage, including the tradition of radical reformism. In other words, it must not abandon the critical reflection on capitalism. At the same time, however, social democracy must remain connected with the libertarian tradition of human rights that defend individual autonomy. However, as regards the delimitation of the notion of liberty, social democracy should not be confined to a narrow perspective, which approaches the individual as being in a condition of 
struggling to survive and therefore is responsible only for himself. This view considers the individual free as long as it is not dependent on the state and to the extent that it pursues selfish individual goals. On the contrary, social democracy seeks a meaningful concept of freedom, which is not confined to the individual but is linked to social conditions [63]. In this respect, the individual is free when it enjoys social security and equal opportunities. Despite the fact that the above principle was registered through the historical struggles of social democracy in the value code of modern Western democratic societies, the percentage of people who are really free is not too high. Poverty, absenteeism (for example the increase of the social vulnerable group of NEETs), unequal education and training opportunities, unemployment, inadequate health care and, in general, the increasing problems of access to social goods, signal the prevalence of conditions of freedom [64].

Therefore, for social democracy, the state is an important tool that produces freedom, not just a tool that reduces it. As a result, social democracy's main aim is to create a welfare state in conjunction with a social market economy as a prerequisite for freedom. However, during the crisis, social democracy manifested its great ideological gap without the proper political narrative, the necessary ideas and an innovative conceptual framework in order to resist the dominant neo-liberal discourse and, therefore, to create a viable social future beyond capitalism. This void is expressed by the paradox that the social democracy lacks a new narrative for the state together with a real social democratic philosophy of justice. Social democracy that has been socially righteous for a century in a dividing line with bourgeois and demand more social equality but has no corresponding theory of justice which could inspire it to the necessary reformation of the welfare state, has no clear future [42].

The necessity of reforming the welfare state is de facto the result of the increased fiscal pressure created by various transformations such as demographic aging, globalization and the individualization of societies. Limiting social democracy to a moralistic debate about the abhorrent modern tendency for social cuts does not negate the obligation to formulate a coherent policy proposal for the construction of a new welfare state, capable of creating measurable social justice objectives and fiscal balanced rules. Those past reflexes that set social benefits above the rules of rational financial management do not necessarily correspond unconditionally in a new theory of social justice. It is therefore necessary, as Judt [61] points out, against the unsuccessful utopia of a pure, uncontrolled capitalism-a radical market economy-for social democracy to recall some principles that are often successfully hidden. In any case, the principle of the "economic value of social policy", the existence of the welfare state, in which capitalism and bourgeois operate much better, as long as they set the foundations of unimpeded social reproduction through the liberalization of the individual from need and danger [65].

Surely, the welfare state as we know it was not necessarily a perfect mechanism for the automatic elimination of social inequalities and the promotion of common good. Anyone who defends the welfare state and the public sector must 
effectively claim its horizontal and vertical reform. Everyone who seeks this reform needs broad alliances, support for the traditional working groups, employees of precarious social groups, farmers and the middle socioeconomic groups. Anyone who attempt to implement such a political strategy should not therefore be satisfied with the role of the "lawyer" of the welfare state, social transfers and dependents on public services, which actually lead to irrationality and passivity. A serious and wider program of transformation of the state with sufficient depth and without easy populist slogans should be the main objective. The policies of privatization and the superstitious belief in the infallibility of "markets" have created a huge negative social impact in several different levels. Such an example is the privatization of the railways in Great Britain [66].

However, the answer to the catastrophic privatization policy should not be nationalization, but advanced, sustainable and democratic forms of the public economy that include the state but not their management form the state. Without the adequate and flexible provision of public goods and services that can be used regardless of its purchasing power or position in the market, equality and freedom of citizens is not able to be achieved in capitalist economies. This is the purpose of the de-commodification of public goods, which is one of the basic pillars of the welfare state [37]. If the public space, the public sector, as the foundation of democracy and as a reasonable counterpart in the private sector, does not acquire a material basis, it will inevitably become degenerated into a rhetorical form. Thus the main objective should focus on the creation of a democratic economy that produces, distributes and uses public goods and commodities, with a universal basis and distribution. Such a system will surely have a serious and necessary involvement and the private sector.

The social democratic model can be revitalized through a new theory of social justice focused on the state and the freedom of the individual. Theoretical sources from which social democracy can draw valuable conclusions are diverse and not limited to dogmatic choices. From the liberal political philosopher vonHayek [67], who generally deny any involvement of the state in the free economy, there is a clear demand to ensure-through social transfers-that the state includes a minimum level of financial resources for those unable to sustain themselves. According to Hayek, legal equality is required in conjunction with the maximum freedom of financial contracts, with minimal social security through state transfers [67]. Hayek [68] proposes the individual autonomy of the public policy field. Rawls follows this position, but considers, on the contrary, that social justice is not a matter of individual virtue but of institutional regulation. The market, according to the philosopher, has unlimited possibilities for distribution in the economic field, but it is not capable of creating social justice. In a sense, Rawls finds a moral blindness in the market, which leads to unequal and unfair conditions of access to it. Consequently, it states that individuals must endow independently of individual abilities, family biographies, social classifications, cultural or race differences, with a bunch of equal basic goods to repair the "scandalous lottery of fortune" and the unequal initial social conditions [68]. 
Therefore, according to Rawls, the economic, political and social structure of societies must include institutions that will fairly distribute those goods that are important for ensuring equal opportunities. These basic goods are rights, freedoms, opportunities, income and wealth and, in general, all the social conditions of a dignified living. Rawls reports two distribution principles. The first [69] calls for an absolutely equal distribution of basic freedoms and civil rights. On the basis of this principle, each individual has equal right to an extended and fully adequate system of equal freedoms compatible with an identical system of freedom for all. This rule is not disputed in modern democracies and is usually applied to the rule of law. The second [69] principle focuses on socio-economic equality, according to which socio-economic inequalities are permissible only when they benefit everyone. Above all, however, the principle should foresee that a potential socio-economic inequality must benefit the most socially vulnerable. In other words, socio-economic inequalities should be subject to a management which makes such arrangements that will benefit the most disadvantaged and secondly to positions-opportunities which are open to all in conditions of fair equality of opportunity. In essence, this rule can be translated into the ability of a society to allow inequalities in favor of the privileged if they also bring advantages to the socially vulnerable.

Rawls's liberal view is consistent, according to Merkel [68], with a modern social democratic concept for at least three distinct reasons:

1) The starting point of Rawls's narrative is uncompromisingly linked with the autonomy and awakening of the individual, and corresponds best to the values, patterns and orientations of post-industrial societies of the 21st century.

2) The provision of the first redistributive principle of equal distribution of freedom and civil rights on a large scale, secures the individual against autocratic and paternalistic tendencies of the state. This view also corresponds to the developed individuality of modern societies.

3) Despite the priority of individual freedom, the second principle of justice requires a major redistribution to the extent that it serves the creation of real equal opportunities for living.

Based on the above, Rawls's view serves the fundamental social democratic values of freedom, justice and solidarity. In addition to the Rawls's view, it is possible to extract applicable policy planning such as integration into education, the labor market, and the activation of an extensive welfare state. Relying on Rawls's agenda, Merkel [68] formulates five specific pillars of social democratic justice in modern societies. These five pillars are further clarified and analyzed in this text and are complemented by a sixth, which deals with immigration policy. Specifically:

- Priority should be given in preventing poverty, as a way to promote individual dignity, integrity and autonomy. It is only when the person is able to exceed the poverty threshold that it can take on the opportunities for development, integration into modern societies and enjoy the fundamental right of freedom. This is to a large extent achieved by Rawls's first principle of justice, 
in which he demands a right to an extended system of equal fundamental freedoms for all [68]. After all, poverty acts as a mechanism that reproduces not only income and material inequality, but also the inability to gain access to fundamental freedoms, essentially making second and third-class citizens. Therefore, poverty prevention is a fundamental criterion for a modern democratic welfare state, in the sense that it defends the fundamental right of freedom.

- Education and training should be bolstered. According to Merkel [68], public investment in education is necessary even if it generates public debt as long as they consecutively lead to the restoration of the fiscal balance through a cut in resources from pension systems. In particular, intensive investment in tertiary education that takes into account the needs of the market, modern requirements in new technologies, know-how and innovation, gives recipients the opportunity to be more easily included into the labor market and, furthermore, to secure high quality jobs with a high income level. At this point, the estimates of vonHayek [67] and Walzer [70] agree as long as the transcendent value of knowledge generates added value and future prosperity for developed societies, further enhancing the decent individual's living opportunities. At the same time, however, the issue of the criteria for the distribution of education is raised, and in particular, whether these should be different in terms of performance criteria. It is obvious that the efficiency model leads, under certain social conditions, to inequalities, partly due to the uneven allocation of performance capabilities. Those who agree with the performance criterion, believing that they are the most expensive, usually hold concessive and monopolistic positions in society, as Walzer points out [70]. However, a social democratic approach to education has as its starting point the criterion of the need for the distribution of social goods. According to Walzer [70], justice is a practical and fragmentary issue that varies according to the political context. Therefore, societies are differentiated into a variety of educational institutions with mass or elitist education systems. This pluralism is necessary because otherwise we are leading to systems of simplistic equality.

But it is impossible to overcome all the differences in complex and modern societies. Thus, according to Walzer [70], the effort to distribute social and educational goods in particular, should be accompanied with the principle of avoiding concessive situations in which certain groups assume a privileged position on all spheres of social and educational goods. In this sense, a just society attempts to overcome the emergence of forms of dominance by distributing social goods for distinct and internal reasons in every level of justice. This model is called composite equality. A variety of goods are distributed based on a variety of distribution procedures, criteria and institutions, and there is no central exclusive decision point, a closed group of intermediaries distributing goods or a single access point [70]. Walzer introduces three educational distribution mechanisms: market-based, efficiency-based and need-based. The thinker empha- 
sizes on the limited power and legitimacy of the three distributive criteria in specific areas of educational justice, distinguishing between basic education provided with universality criteria and specialized and vocational training for the minority. In primary education, the criterion of necessity, which has social characteristics and does not refer to criteria of individual choice, is indeed valid. Basic education in other words, as Walzer puts it, corresponds to the model of equality as a form of equal social provision to children engaged as future citizens [70]. On the contrary, the sector of specialized and vocational education concerns the minority and serves the needs of the labor market [70]. In any case, Walzer's approach emphasizes on the need for a choice based economic efficiency, market absorption, and the cogent need for education. Finding a job and building a person with specific skills should be a key criterion for education for social democracy.

- Inclusion in the labor market is another basic prerequisite for social democracy as long as income, prestige and identity are distributed to citizens. Ultimately, unemployment is not a purely economic problem solved by courageous transfers but a moral issue in the sense that it affects individual autonomy, dignity and enhances the reduction of opportunities for recruitment. This is particularly true in the case of long-term and youth unemployment. According to Oreopoulos et al. [71] and Mroz \& Savage [72], youth unemployment can lead to remarkable future salary reductions. Bell \& Blanchflower [73] go one step further by finding that there are indications that long-term social and psychological problems arise for workers who, when they were between the ages of $15-24$, were unemployed while possessing (and still possess) limited skills and education. Thus, the importance of these problems is understandable with regard to the future outcome of exclusion leading to a reduction of freedom. According to Sen [74], forced exclusion from the labor market is perceived as a loss of freedom while the labor market crisis has as a whole, a limitation on the European idea of human rights. Sen describes equal opportunities and participation in social production as the ultimate goal of the welfare state, which guarantees freedom of decision as an inalienable human right. In his view, unemployment is not only related to income loss but also increases social inequality by increasing poverty. Poverty produces anxiety through dependencies, loss of free-will, and ultimately an alienation experience for the unemployed. In addition to the loss of freedom and social exclusion, as a consequence of unemployment, Sen [74] identifies in his empirical research a trend of loss of skills, cognitive competence and motivation, exacerbation of mental and physical diseases, mortality, ethnic and racial inequality and social insecurity in the sense of loss of social values and the reduction on level of responsibility.

The above-mentioned effects of unemployment affect the foundations of social cohesion of modern societies and ultimately threaten even democracy itself. As Wilkinson and Pickett [75] demonstrate in their empirical research, the degree of social cohesion, trust and effective functioning of societies depends to a large extent on the level of equality. In countries where there is greater equality 
in income distribution, such as Japan and less unemployment, such as the Scandinavian countries, citizens show a greater degree of mutual trust and societies have a lesser degree of impunity. The same applies to the extent of exposure to illness and life expectancy. A modern welfare state, with rule of law, is interested in the emergence of individual dignity through labor biography and not by providing basic income and welfare benefits on the basis of loose criteria, which in fact facilitate the abandonment of any labor integration effort leading to exclusion and stigmatization [76] of those who have real need for benefits. Therefore, social standards of supply need to be revised where they hamper labor market dynamics by generating long-term unemployment. Resources in this area are indispensable even if they lead to cutbacks from other social security areas.

- High social security standards should be on the core of the social democratic agenda. In this level, however, security measures can be incorporated, such as the intensification of the beneficiaries' obligations to return to work. It is important to mobilize all possibilities for labor market integration to prevent people from resorting to social care and welfare solutions. Measures such as the transfer of funds to areas such as education and employment integration will need to be taken instead of a constant increase in resources to the state's administrative responsibilities and to pension funds. At the same time, tax cuts in the field of work and tightening of work commitments will be necessary. Scandinavian countries are a prudent example of investment in education, active labor market integration policy with individual absorption plans for all unemployed and implementation of preventive social protection measures under conditions of strict obligations on beneficiaries and strict sanctions against tax evasion and abuse against the welfare state. Such measures promote social justice without disturbing economic development.

- Income distribution should be another basic social democratic objective, because in this field the market and state activity are reflected. A primary objective in this area is to avoid further opening of the income gap. This policy measure does not have the same priority over the abovementioned, because if there are effective positive outcomes in the fight against poverty, education promotion and labor market integration, then the income gap will be limited partly automatically. However, the minimum goal should be not to increase the income gap to such an extent that social cohesion can no longer be maintained through social policies.

- Addressing the immigration and refugee issue. The modern welfare state encounters new refugee trends arising from the political and social crisis and the wars that plague the countries of the South East Mediterranean and the Middle East, such as Syria, Libya, Iraq, Egypt and Tunisia. At the same time, it addresses the problem of social integration of first, second and third generation migrants.

A modern immigration policy has to face two parallel challenges. On the one hand, the new refugee flows must be channeled in such a way that the humanitarian obligations arising from the international conventions on asylum and refu- 
gee protection are respected, and on the other hand, it must be understood that the issue of refugees' and migrants' integration has become permanent in politics and society. It is obvious that a European Union without internal borders requires a coordinated immigration and asylum policy. Social democracy on this issue has always supported the principle of continual intensification of common policies under the conditions of maintaining the necessary national policies. Given the spreading of the terrorism danger across Europe, it would be naive to believe that no common restrictive measures are needed. But the main objective must be to implement an active, modern and integrated immigration policy that will include measures against illegal immigration, along with the adoption of prevention plans. Social democracy advocates a system of points for inviting highly qualified and skilled workers and for a policy input into productive sectors that are in need. In addition, however, there will still be demand for less-skilled workers. Through the implementation of policy measures that safeguard social and labor rights, the illicit overexploitation of immigrants can be addressed. Where the principle of "equal pay for equal work at the same place" is avoided, the payroll and social reduction of these groups could be avoided, while at the same time, immigrants are treated as equal and skilled in triggering growth. Social democrats also support a policy of a "European Blue Card" for highly qualified third-country nationals, enabling the EU to become competitive with other labor markets in the recruitment of qualified staff. The Blue Card should also incorporate a range of socio-economic rights. At the same time, however, the concept of highly qualified staff should be supplemented and clarified on the basis of professional experience, in addition to the formal qualification criteria.

The above basic strategic priorities of a new welfare state require a specific lever of implementation which at present should not be anything other than an active state at national level combined with the contribution of existing supranational institutions.

\subsection{The Active State}

Obviously, social democracy should not abandon its ability to reformulate its policies. In a globalized world a new reform policy means networking, transformation and human-centered mutation of existing institutions. The new reform perspective must include specific and measurable objectives, such as a fair distribution of income and wealth-both nationally and globally-reduction of income inequalities between men and women, reduction of relative and absolute poverty, and ultimately, suppression of economic power in its influence over political decision-making.

The dismantling of the welfare state that took place throughout the 1990s and was intensified by the outbreak of the international economic crisis has been the result of specific political decisions. Thus, new political decisions should be launched in the same way, which will overturn restrictive policies to the extent that fiscal sustainability is assured or at least political decisions are made to distribute burdens more fairly. As mentioned above, the state was activated in the 
midst of an economic crisis to curb economic upheaval. In the same way, it can be activated in the future and become an active state in specific policy fields. In this regard, the first policy field which should be given emphasis, is the social policy, as outlined above.

As evidenced by the socio-economic data of the 1980s and 1990s and during the crisis, welfare systems in Europe have not been able to reduce unemployment or social marginalization in the long run despite the constant increase in social spending [59]. Currently, about 25.9 million people are unemployed in the EU and 5.2 million of them are aged 18 - 24. An age group which made up just $13 \%$ of the total of working age (defined as $18-64$ ), therefore, accounted for $20 \%$ of the total unemployed. Rates of unemployed among this age group were as high as $50 \%$ in Croatia, 55\% in Spain and 58\% in Greece and were only slightly less than $40 \%$ in Portugal, Italy and Cyprus (Figure 2). It is also obvious that a substantial proportion of young people aged 15 - 24 were neither employed nor in education or training (what have come to be known as NEETs), reaching $19 \%$ in the EU in 2013. While the majority of this group were unemployed (just over $10 \%$ of the age group), $45 \%$ were inactive, in the sense of being out of work and not actively seeking employment while not participating in education or training (Figure 2).

Nordic countries show high level of effectiveness in tackling youth unemployment through public policies. When in 1997 youth unemployment was at its peak in Sweden, the government set up a five-year program to increase young people's access to education and training. The objective was to reduce unemployment by half by the year 2000 by offering one year of full-time education to unemployed people who did not complete secondary education. Parallel goals were the structural reform of education and labor market, the increase of training opportunities for early school leavers and the increase of growth dynamics of the economy [77]. Inequality has been reduced both in terms of access to education and educational performance in all municipalities as well as the rate of unemployment. As far as Finland is concerned, it has actually suffered an even greater recession than Sweden in the early 1990s, while GDP fell by $10 \%$ in 1990-1993 and unemployment increased by $15 \%$ as a consequence of the collapse

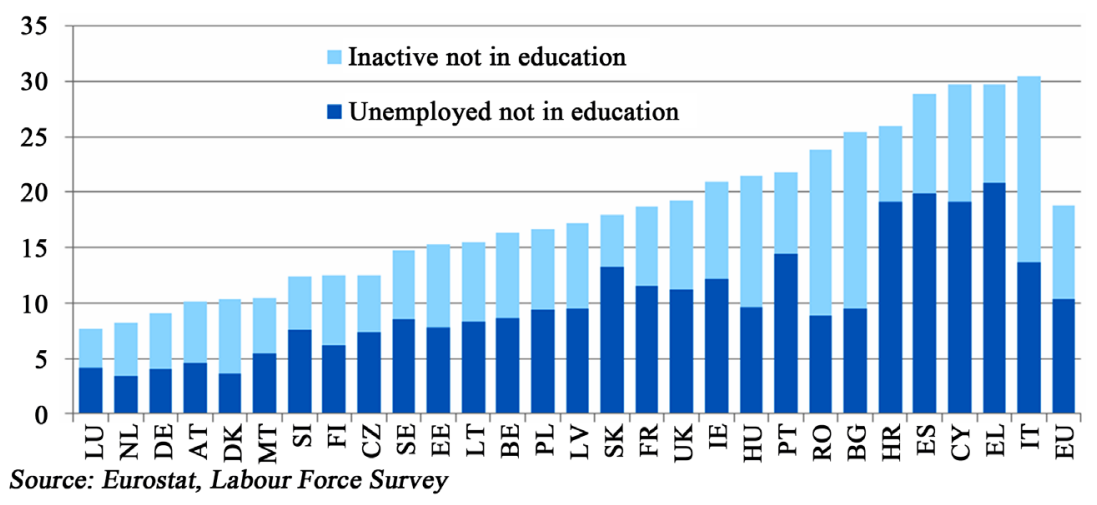

Figure 2. Proportion of people aged 15 - 24 not in employment, education or training, 2013 (\% age group) [77]. 
of the Soviet Union that coincided with the global recession. This has led to a major review of the economic strategy, with increasing emphasis on technological progress and the development of a knowledge-based economy. It was acknowledged, however, that there was no need only for investment in technological infrastructure or innovation, but also to a well-trained workforce. Human capital and skilled labor are crucial to the production of new technologies, but the demand side is equally important. Under such policies the new technologies are not disseminated and adopted without user training. Moreover, the Finnish education system emphasizes on gender equality as well as regional and socio-economic equality. Equal opportunities for all, is the guiding principle. Everyone receives the same basic education and education is free up to the university level [77]. As a result, not only Finland is spending on education the highest proportion of GDP in Europe, but the country is in the top places of the World Bank's indicator on knowledge economy and the PISA index that measures student skills.

However, at the time of the crisis, the EU Member States generally followed the examples of Finland or Sweden. Expenditure on both education in general and on tertiary education has been decreased in several countries, particularly those that the crisis has hit the most. In the EU-27, real-time education costs were increased by just $1 \%$ during the 2008-2012 and by $9 \%$ over the previous four years (Table 4). In 14 of the 27 countries, including Greece, Spain, Ireland and the three Baltic countries, the corresponding costs have been decreased, as the impact of the crisis was particularly severe. Some countries had an opportunity to expand spending on higher education in a context where more young people were trying to delay their entry into the labor market due to job shortages. Except Sweden, therefore, only in Malta, Denmark and France there was an increase in expenditure in tertiary education in real terms in the four years 2008-2012, compared to the previous four years [77].

All the above mentioned highlight the fact that even under difficult circumstances public policies can inhibit the effects of the economy. The problem of social spending inefficiency and the one-dimensional redistribution policy, however, have been important causes for the subsequent cutback and privatization of social services by neo-liberal governments. Therefore, the new active state must implement a responsible and financially stable social policy, which will focus on preventive functions and on a certain degree of selectivity, in the sense of a more rational social policy in defining target groups and stricter definition of criteria for providing social services to specific beneficiaries. The uncontrolled universality of social policy leads to exactly the opposite effect in the midst of fiscal derailment.

The preventive function of the state must focus on the issue of work, namely the effective reduction of unemployment. This can be implemented by focusing on the knowledge society and investing in education, training, inventiveness, new technologies and innovation. The direction of integration into the labor 
Table 4. Expenditure on education in real terms, 2004-2008 and 2008-2012 (\% change).

\begin{tabular}{|c|c|c|c|c|}
\hline & \multicolumn{2}{|c|}{ Total } & \multicolumn{2}{|c|}{ Tertiary } \\
\hline & 2004-2008 & $2008-2012$ & 2004-2008 & 2008-2012 \\
\hline EU27 & 9.3 & 0.8 & 22.3 & -2.7 \\
\hline Malta & 6.8 & 16.5 & 8.9 & 43.6 \\
\hline Luxembourg & 10.5 & 15.9 & 117.6 & 76.6 \\
\hline Slovakia & 19.0 & 15.2 & na & na \\
\hline Germany & 5.2 & 12.0 & 15.7 & 14.4 \\
\hline Denmark & -3.1 & 9.6 & 5.4 & 20.5 \\
\hline France & 2.8 & 8.8 & 15.9 & 46.1 \\
\hline Belgium & 11.4 & 8.1 & na & na \\
\hline Poland & 23.9 & 7.0 & 98.3 & 4.6 \\
\hline Czech Republic & 20.5 & 6.7 & 58.7 & -5.6 \\
\hline Austria & 14.2 & 5.1 & 36.3 & -2.7 \\
\hline Sweden & 6.8 & 4.7 & -2.0 & 8.6 \\
\hline Netherlands & 9.5 & 4.0 & 27.3 & 7.6 \\
\hline Finland & 6.5 & 3.6 & 9.5 & 8.0 \\
\hline Slovenia & 15.0 & -3.8 & 17.7 & 7.6 \\
\hline Estonia & 30.9 & -4.1 & 112.8 & 6.7 \\
\hline Cyprus & 23.4 & -4.2 & 64.5 & -15.9 \\
\hline Ireland & 31.0 & -6.5 & 45.6 & 6.1 \\
\hline UK & 20.4 & -6.6 & 20.5 & -11.9 \\
\hline Lithuania & 32.1 & -7.9 & 86.7 & 16.9 \\
\hline Spain & 18.0 & -8.4 & 28.5 & 1.4 \\
\hline Italy & 0.0 & -10.9 & 13.1 & -13.5 \\
\hline Hungary & -1.0 & -13.7 & 14.3 & 2.7 \\
\hline Portugal & -3.2 & -14.2 & -6.1 & -13.8 \\
\hline Bulgaria & 28.6 & -17.4 & 66.6 & -9.2 \\
\hline Greece & 18.3 & -20.7 & 73.7 & -18.2 \\
\hline Latvia & 41.1 & -25.1 & na & -16.2 \\
\hline Romania & 58.6 & -36.0 & na & -44.4 \\
\hline
\end{tabular}

Note: The figures show the change in nominal expenditure converted to real terms by the GDP deflator. The figure for Spain for tertiary education in the final column refers to 2008-2011 Source: Eurostat, General Government expenditure by function.

market and innovation must define the educational process from infancy to the phases of vocational training and tertiary education.

For the preservation of the welfare state, consensus is required of the middle socioeconomic groups. Accordingly, the services provided should not only be mentioned in the fight against poverty but should include, protect and cover the 
middle socioeconomic groups on a large scale. Ultimately, citizens are willing to pay for the maintenance of the welfare state when they feel they enjoy their efficient services and when they see visible results for society as a whole. The welfare state needs the implementation of a strategy focused on strengthening the provided social services, reducing administrative costs, procurement cost, corruption cost and customer interconnection, and the cost created by the consolidation of trade unions and interest groups throughout the hierarchical legal scale of the state. A second large field of active policy for the state is the regulation of markets. Contrary to the speculation of neo-liberal narrative, the international crisis has clearly demonstrated that markets are not able to be self-regulated but require the regulatory role of the state.

Consequently, the active state has to negotiate conditions for effective competition for private sector companies and respond to the establishment of an efficient, proportionate and equitable tax policy, as well as to the need for public investment in infrastructure and new technologies. On the other hand, the state can also play an active role in the economic process by creating a framework of incentives and sanctions that will regulate the conditions of competition and future market trends. Examples could be the promotion of new, innovative technologies in all fields of production and especially in the field of energy efficiency, in the expansion of quality services, particularly in the health and welfare sector, the social economy and innovation in the agricultural sector. Public policy should be aiming at creating the conditions for proper functioning of the real economy towards the financial economy, which must also be taxed. At the same time, it means effectively combating the shadow economy. In Greece, for example, the level of shadow economy is estimated at 35\% of GDP, or about 60 billion€ annually. A reduction in the shadow economy would accordingly reduce the debt/GDP ratio [78]. State intervention is also required in order to achieve a fairer tax policy that is also an indirect way of providing social policy and redistribution. In Greece, for example, tax burdens are totally distributed unequally in the sense that salaried and retired people pay $52.59 \%$ of total income tax. At the same time, seven out of ten freelancers (doctors, lawyers, notaries, plumbers, electricians, etc.) show low incomes [78].

As it can be easily seen in Figure 3 in countries where there is an extensive but effective welfare state intervention (Denmark, Finland, Sweden) the Index of Social Progress which measures parameters of basic human needs along with wellbeing data and equal opportunities [79] is higher. This can offer us crucial evidence of the proper role-direction of the state that social democracy should implement in order to achieve its fundamental objectives and create a socially fairer and equal framework and at the same time depicts the differences between the restrictive and expansive social policy in terms of their social impact.

However, it is obvious that under the conditions of financial markets dominance due to their gradual deregulation, together with their ability to control liquidity flows and to offer high opportunistic motives, policy tools are limited to national state. This requires regulation of financial capitalism at European and 


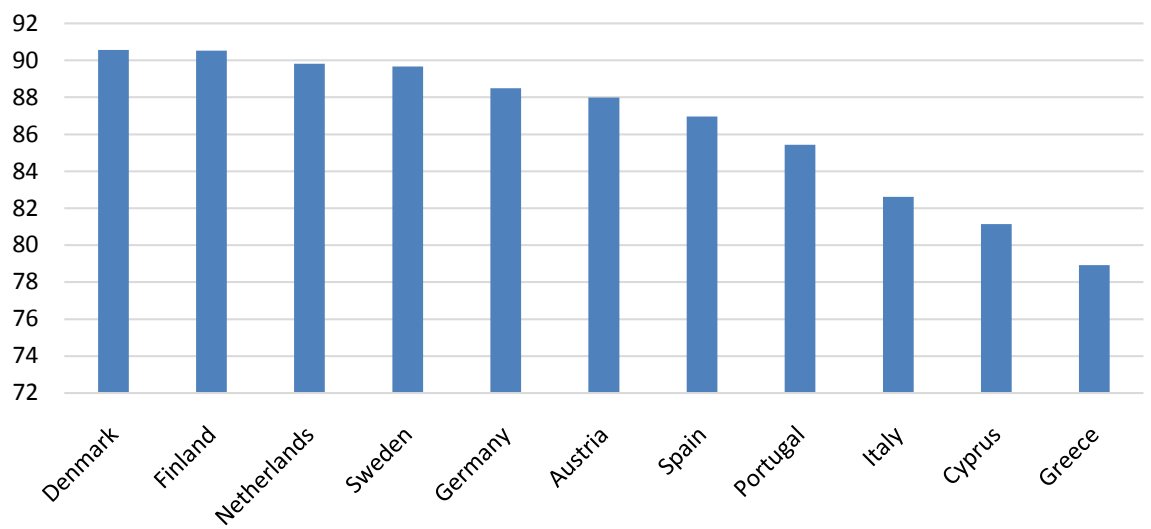

Figure 3. Social progress index in selected European countries.

international level. The methodological tools for translating the new reform vision have already been put on the public agenda and are expressed through concrete proposals for measures such as the introduction of Eurobonds, a Tobin tax, an EU tax and the inclusion of investment income in social systems insurance. In any case, the new reformism must escape the multiple historical stereotypes and be permeated by such new orientations.

The new reform agenda is meaningful in all areas where policy is being pursued. This concerns the national state, international organizations, and the so-called "private governance regimes", as well as non-governmental organizations and communities. Approaches such as Fair Trade or Creative Commons are not, of course, immediate and unique solutions to the problems of international trade, but they are a step forward, particularly in transnational areas where there is a clear lack of the minimum possibilities for state regulation.

A new reform policy can be implemented within existing systems so that they become systematically more democratic, socially more just and more transparent. This logic follows, for example, from criticism towards the EU and the struggle for an EU Reform Treaty that certainly does not go beyond its neo-liberal constitutive principles but reduces it. Based on this, there is a demand for reform of international organizations such as the International Monetary Fund (IMF), the World Trade Organization (WTO) and the United Nations (UN).

\section{Concluding Remarks}

Throughout Europe, social democracy has no longer enjoyed the ultimate advantage in the lower income groups. However, it ought to act unreservedly as a proxy of workers and socially excluded. Policies to prevent poverty, to promote full-time employment through integration into productive models that produce both innovation and labor intensity as well as through active labor market integration policies, the provision of extensive career opportunities and education, income redistribution, the de-commodification of health, coupled with a budget-tolerant system of total coherent social security, are old measures that need 
updating and adaptation to the data of limited budgetary resources in order to keep alive the fundamental value-orientation of a progressive reform based on social rights.

According to these rights, people have a legitimate right to freedom from discrimination, old-age security, social security, in the sense of a universal citizens' insurance that protects them against direct dangers and prevents the creation of new, as well as the right to be able to meet their basic needs. Recognition of human social rights leads not only to the need to seriously consolidate basic minimum income models, but also open the possibilities of protecting and decoupling humans from financial control mechanisms and state arbitrariness. Citizens in welfare states have since their birth the right to social benefits and are not subject to the state, nor are a free prey of the market. Protection of these social rights is therefore the primary pillar of the state's active presence, which must meet the requirements set in the new era. As a result of this, the new state is an integral and obligatory part of the structures of the welfare state, and social democracy must defend this continuity in order to ensure the improvement of the living conditions.

It is obvious that the continuing economic downturn is likely to lead to further job insecurity and a possible offset to this may be the willingness of companies to negotiate other aspects of security and quality of work benefits such as support for family responsibilities [80]. The research on social democracy should not ignore the abovementioned limits of public policies due to the economic crisis. Furthermore, public sector employment, which is associated with the highest satisfaction of work and private life balance, has been drastically reduced in many countries with further cuts in progress. Also, social benefits, such as those supporting parents have been severely curtailed. Meanwhile, the cost of childcare for parents is rising, even when family incomes are stagnant or declining.

It is, however, certain that the impact of the crisis on the reconciliation of work and family-private life will vary considerably depending on the economic and political environment of each country as well as on the differences between the various sectors of activity (public-private), the size of the business [81], and on the extent to which equality policies are being promoted. Research on social democracy today cannot ignore the latest phenomenon of governance, which is a more flexible and effective scheme that moves away from the traditional bureaucracy and makes it "open" to the institutional partners of Civil Society. Key aspects of governance include New Public Management, the increasing importance of non-governmental forms of governance, the existence of policy networks and the new political economy which aim at regulating rather than providing services [44]. On the other hand, however, there are also opportunities for social democracy that should be taken into account in the research.

Many voters fear the anonymous forces of globalized capitalism, which lead directly to job insecurity, low paid work and reduction of living conditions. They are afraid of these factors because social issues such as unemployment and illness can lead to a large loss of income and consequently to social vulnerability. 
They are afraid to lose their existing poor prosperity and their lives become unbearable because basic goods are becoming more and more expensive. The voters are subject to great uncertainty because for years the state is constantly cutting expenditure for its citizens. At the same time, European citizens are afraid of the dubious and partly inhumane handling of refugees by many interior ministers in Europe with the image of miserable camps and a busy public debate that creates the feeling that a flood of refugees across the borders of Europe is waiting for the moment to plunder the privileges of the European welfare states.

During the greatest capitalist crisis since the 1930s, social democracy currently has limited answers or solutions. This void is filled with the far-right populist parties which believe that the powerless refugees are responsible for the morbid manifestations of capitalism in crisis. However, right-wing populists can only cultivate phobias when rational models of interpretation and alternative strategies are lacking. This is an incentive for future research. The search for rational models of interpretation of the capitalist crisis combined with a new interpretation of the welfare state appropriate to post-crisis social democracy and, in conjunction with it, the research for realistic and financially viable alternative strategies to promote social justice and cohesion, considering migration as a part of the solution rather than a part of the problem. The loss of the worker electoral basis for social democracy symbolizes the loss of its credibility. The world of work is no longer assured that social democracy can solve the problems that arise in the daily life of work and privacy. In this respect, social democracy is responsible because, in a framework of increasing unemployment, it has only rhetorically condemned European austerity policies while at the same time supported them practically. In many cases, social democratic governments have, without resistance, implemented the hard austerity programs. Under these circumstances, the fact that they lose credibility should not be surprising. Just because simple slogans about social justice are not enough to solve the major problems faced by the world of work, a structured scientific research is also required in this field that will detect the multidimensional problems and propose viable solutions. Surely, the point of view of such an analysis must be that of pragmatism, because the resources available define both policies and research itself. In any case, social democracy needs a policy that will solve identifiable social problems. The arguments of the populists have crucial electoral impact. Social democracy will be able to address the challenges and the positions of populists with realistic views on social issues.

Why should people's indignation for their daily routine be directed against asylum-seekers and not against public structures? Why not to try to propose specific public policies instead of racism? The proposed solutions range from nationalization and the reduction of the financial sector to a different fiscal policy, by investing in the educational and social system, reducing housing rent, increasing social housing, reducing working time and increasing democratic control of large enterprises. Thus, social democracy can return to a position of po- 
litical hegemony only if it opens the dialogue on the idea of common values for the common interest [61].

It turns out that social democracy has the advantage over other political ideologies as long as it comprises the historical experience and knowledge to reopen the public debate on what is today a collective-public good, how and by whom it can be offered, who will benefit, how to reconstitute the alliance between middle and weaker socio-economic groups and to reconcile labor with capital and thus, with the market. The proposed solutions do not come from the past, but the questions remain the same and are vital. The social issue must again be at the heart of the public debate. Only if social democracy regains the reign of politics as a process of promoting collective interests and democracy, it can displace the current dominant economic doctrine over policy that is cultivated by both the neo-liberal and the Marxist narratives. As Berman points out [82] "as the great social democrats of the late nineteenth and early twentieth century recognized, the most important thing politics can provide is a sense of the possible. Against Marxist determinism and liberal laissez-fairism, accordingly, they pleaded for the development of a political ideology based on the idea that, in spite of everything, people working together could and should make the world a better place: the result was the most successful political movement of the twentieth century. The problems of the twenty-first century may be different in form, but they are not different in kind; there is no reason that the accomplishment cannot be repeated". All these issues are passing through the state which has the potential to overcome crisis and populism and to give new impetus to social cohesion through conflicts that inevitably intercept, delimit and partially contest capitalism. As Kenworthy [83] notes, "for the better or worse, the new hypercompetitive, risk-filled economy is here to stay". But just dominating markets and competition is the biggest obstacle to the political rebirth of social democracy on the other hand, far-right populism challenges the fanaticism of capitalist sovereignty by cultivating hopes and aspirations for a better world. All of these data fundamentally demarcate the social-democratic perspective. As Harrington [84] points out, "the fact is that as long as capitalism is capitalism it vitiates or subverts the efforts of socialists... In fact, capital fights back, it does not meekly accept the programming of social democratic ministers... economic power is political power, and as long as the basic relationships of the economy are left intact, they provide a base for the subversion of the democratic will." The long retrenchment of twenty-century victories across the advanced capitalist countries has borne out that prediction many times over.

However, there are too many arguments that they state that almost a century after "it officially began, the contest between capitalism and socialism is over: capitalism has won" [85], because they conceal the fact that social democracy never aimed to cease capitalism but to humanize it, something that it had greatly succeeded after the World War II. Therefore, a decisive point in this direction is what can be accomplished by a governmental responsibility place in the current conditions. At this point, the phrase of Willy Brandt makes sense, that it makes 
no sense to be a social democrat in the government if you cannot implement social-democratic policies. Therefore, the research for social democracy in the future should focus on the different ways and methods that it can regain the public trust through a revitalized narrative about the welfare state and not through the pure defense of just keeping the governmental positions.

\section{References}

[1] Dahrendorf, R. (1983) Die Chancen der Krise. Über die Zukunft des Liberalismus. DVA Verlag, Stuttgart, 16-17.

[2] Dahrendorf, R. (1987) Fragmente eines neuen Liberalismus. DVA, Stuttgart, 91.

[3] Walter, F. (2010) Vorwärts oder abwärts? Zur Transformation der Sozialdemokratie. Suhrkamp, Berlin, 43.

[4] Heimann, E. (1980/1929) Soziale Theorie des Kapitlismus. Theorie der Sozialpolitik. Suhrkamp, Frankfurt, 88-89.

[5] Heidorn, J. (1982) Legitimität und Regierbarkeit. Studien zu den Legitimitätstheorien von, 154-155, 257.

[6] Berman, S. (2009) The Primacy of Economics versus the Primacy of Politics. Perspectives on Politics, 7, 561-578. https://doi.org/10.1017/S1537592709990867

[7] Hardt, M. (2010) Wir müssen verstehen, wer der Feind ist. Der Spiegel, 1. http://www.spiegel.de/kultur/gesellschaft/neoliberalismus-kritiker-hardt-wir-muess en-verstehen-wer-der-feind-ist-a-685199.html

[8] Harvey, D. (2010) The Enigma of Capital and the Crises of Capitalism. Oxford University Press, London, 227.

[9] Rodrik, D. (2011) The Globalization Paradox: Democracy and the Future of the World Economy. Norton, New York, 165. https://doi.org/10.1355/ae28-3k

[10] Quiggin, J. (2011) Zombie Economics: How Dead Ideas Walk among US. Princeton, University Press, 29.

[11] Beck, U. (2009) "Eine quasi revolutionäre Situation", Der Soziologe Ulrich Beck über die Wut in der Krise, die neoliberale Irrlehre, Gesine Schwan, Angela Merkel und das Versagen der Eliten, 4. http://www.schimmeck.de/Texte/beck.htm

[12] Rüstow, A. (2001) Das Versagen des Wirtschaftsliberalismus. Metropois-Verlag, Marburg, 59, 90-91, 142.

[13] Rodrik, D. (2012) Who Needs the Nation State? Centre for Economic Policy Research (CEPR), Discussion Paper No. 9040, London, 5-9.

[14] Alfaiate, J., Bottini, N., Clarke, S., et al. (2014) 2014 Legatum Prosperity Index. Legatum Institute, London, 3-4.

[15] Legatum Institute (2017) Legatum Prosperity Index. 11th Edition, Legatum Institute, London, 9.

[16] Rodrik, D. (2004) Growth Strategies. Kennedy School of Government, Harvard University, 1005-1008.

[17] Zattler, J. (2004) Post-Washington-Consensus-Einige Überlegungen. Ein Diskussionspapier des BMZ. Herausgegeben vomBundesministerium für wirtschaftliche Zusammenarbeit und Entwicklung Referat für Entwicklungspolitische Informations- und Bildungsarbeit. Bonn, 3, 19-30.

[18] IMF (2003) Institutional Investors in Emerging Markets. Global Financial Stability Report, Washington DC, 75-81. 
[19] World Bank (2002) Building Institutions for Markets. World Development Report, Oxford University Press, 5-26.

[20] Hall, R.E. and Jones, C.I. (1999) Why Do Some Countries Produce So Much More Output per Worker than Others? The Quarterly Journal of Economics, 114, 83-116. https://doi.org/10.1162/003355399555954

[21] Acemoglu, D., Johnson, S. and Robinson, J.A. (2001) The Colonial Origins of Comparative Development: An Empirical Investigation. American Economic Review, 91, 1376-1379.

[22] Rodrik, D., Subramanian, A. and Trebbi, F. (2002) Institutions Rule: The Primacy of Institutions over Geography and Integration in Economic Development. Kennedy School of Government, Harvard University, 22-23. https://doi.org/10.3386/w9305

[23] Fukuyama, F. (2011) The Origins of Political Order: From Pre Human Times to the French Revolution. Farrar, Strauss and Giroux, New York, 450-452.

[24] von Hayek, F.A. (1973/2002) "Wirtschaftsfreiheit und repräsentative Demokratie", in: ders.: Gesammelte Schriften Abt. A, Bd. 5 (Grundsätze einer liberalen Wirtschaftsordnung. Aufsätze zur Politischen Philosophie und Theorie), Mohr Siebeck, Tübingen, 179, 184.

[25] Baur, N. (2001) Soziologische und ökonomische Theorien der Erwerbsarbeit: eine Einführung. Campus Verlag, Frankfurt/New York, 53.

[26] Hayek, F. (1944) The Road to Serfdom. University of Chicago Press, Chicago, 27-31.

[27] Adams, I. (2001) Political Ideology Today. Manchester University Press, Manchester, 20.

[28] Hletsos, M. (2009) The Economic Functions of the State in the System of Market. In: Zoumboulakis, M. and Kollias, H., Eds., Modern Political Economy, Patakis, Athens, 141. (In Greek)

[29] Jessop, B. (2002) Liberalism, Neoliberalism and Urban Governance: A State-Theoretical Perspective. Antipode, 34, 454-455.

https://doi.org/10.1111/1467-8330.00250

[30] Sapir, A. (2006) Globalization and the Reform of European Social Models. Journal of Common Market Studies, 44, 369-390. https://doi.org/10.1111/j.1468-5965.2006.00627.x

[31] Schwab, K. (2017) The Global Competitiveness Report 2017-2018. World Economic Forum, Geneva, 326.

[32] Williamson, J. (1990) What Washington Means by Policy Reform. In: Williamson, J., Ed., Latin American Adjustment: How Much Has Happened? Institute for International Economics, Washington, 7-20.

[33] Bethke, F.S. (2012), Zuverlässig Invalide-Indizes zur Messung fragiler Staatlichkeit. Zeitschrift für Vergleichende Politikwissenschaft 5, VS Verlag für Sozialwissenschaften, Wiesbaden, 1-19.

[34] Heiduk, F. (2010) Staatszerfall als Herrschaftsstrategie, Indonesien zwischen Desintegration und Demokratisierungsblockaden am Beispiel des AcehKonflikts, Baden-Baden, 25.

[35] Jackson, R.H. and Rosberg, C. (1982) Why African Weak States Persist: The Empirical and the Juridical in Statehood. World Politics, 35, 1-24. https://doi.org/10.2307/2010277

[36] Huber, E. and Stephens, J.D. (2002) Globalisation, Competitiveness, and the Social Democratic Model. Social Policy \& Society, 1, 48-49. https://doi.org/10.1017/S1474746402001070 
[37] Esping-Andersen, G. (1990) The Three Worlds of Welfare Capitalism. Polity \& Princeton University Press, Cambridge \& Princeton, NJ, 9-23.

[38] Smith, A. (1776/1929) Reichtum der Nationen. Verlag, Voltmedia GmbH, Paderborn, 743 .

[39] Stefes, C.H. (2006) Der Staat in der Vergleichenden Politikwissenschaft. In: Barrios, H. und Stefes, C.H., Hrsg., Einführung in die Comparative Politics, München, Wien, 178. https://doi.org/10.1524/9783486599176.169

[40] Lauth, H.J. (2004) Demokratie und Demokratiemessung. Verlag für Sozialwissenschaften, Wiesbaden, 125. https://doi.org/10.1007/978-3-663-01617-5

[41] Rüb, F.W. (2003) Staatlichkeit, Staatsbildung und Staatszerfall. Dimensionen und Perspektiven der politikwissenschaftlichen Debatte. In: Bendel, P., Croissant, A. and Rüb, F.W., Hrsg., Demokratie und Staatlichkeit. Systemwechsel zwischen Staatsreform und Staatskollaps, Opladen, 59-60.

[42] Merkel, W., Puhle, H.J., Croissant, A., Eicher, C. and Thiery, P. (2011) Defekte Demokratie. Band 1: Theorie, Opladen, 58.

[43] Croissant, A. (2003) Staat, Staatlichkeit und demokratische Transformation in Ostasien. In: Bendel, P., Croissant, A., Rüb, F.W., Hrsg., Demokratie und Staatlichkeit. Systemwechsel zwischen Staatsreform und Staatskollaps, Opladen, 84.

[44] Ladi, S. and Ntalakou, B. (2010) Public Policy Analysis. Papazisis, Athens, 14, 27-28. (In Greek)

[45] Karagiorgas, D. (1979) The Economic Functions of the State. Papazisis, Athens, 103. (In Greek)

[46] Nordmann, J. (2013) Das neoliberale Selbst. ZurGeneseund Kritik neuer Subjektkonstruktionen, ICAE. Institute for Comprehensive Analysis of Economy InstitutFür die Gesamtanalyse der Wirtschaft. Johannes Keppler Universität Linz. Working Paper Series No. 22 September 2013, 4.

[47] Bieling, H.J. (2001) Transnationale Vergesellschaftung und dieneue Sozialdemokratie. In: Candeias, M. und Deppe, F., Hg., Ein neuer Kapitalismus? Hamburg, 12.

[48] Gauchet, M. (2012) Democracy under the Sufferance of Authoritarianism, 1914-1974. Polis, Athens. (In Greek)

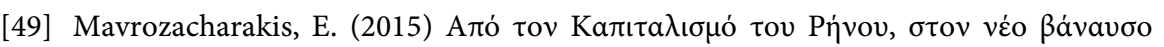

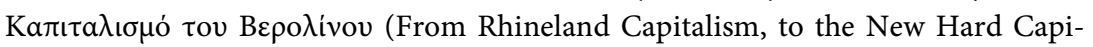
talism of Berlin). 14-24. http://ssrn.com/abstract=2600404

[50] Mavrozacharakis, E. (2015) Das Ökonomische und Politische Dilemma Europas (The Economic and Political Dilemma of Europe). 3-19. http://ssrn.com/abstract=2595091

[51] Von Beyme, K. (2018) Rechtspopulismus: Ein Element der Neodemokratie? Springer Fachmedien, Wiesbaden, 24. https://doi.org/10.1007/978-3-658-19767-4

[52] Mavrozacharakis, E. (2015c) Demokratie, öffentliche Güter und Europa (Democracy, Public Goods and Europe). 8-10. http://ssrn.com/abstract=2595093

[53] Hout, W. (2006) European Social Democracy and the Neo-liberal Global Agenda: A Resurgent Influence or Capitulation? In: Robinson, R., Ed., The Neo-Liberal RevoIution Forging the Market State, Palgrave Macmillan, New York, 228-233.

[54] Hahnel, R. (2005) Economic Justice and Democracy: From Competition to Cooperation. Routledge New York-Oxon, 116-117.

[55] Quinn, S. (2009) Lemon Socialism and Securitization. Trajectories Newsletter of the ASA Comparative and Historical Sociology, 20, 3-4. 
[56] Krugman, P. (2009) Bailouts for Bunglers. New York Times. http://www.nytimes.com/2009/02/02/opinion/02krugman.html

[57] Aghion, P. (2014) The Smart State. Policy Network: Making Progressive Politics Work, London, 25-26.

[58] Lavdas, K.A. and Mavrozacharakis, E. (2015) Räume Der Übertragung: Die neuetransnationale Politik der säkularen Stagnation (Spaces of Transference: The New Transnational Politics of Secular Stagnation). 10-14. https://ssrn.com/abstract=2605493

[59] Pohlmann, C. and Hassel A. (2010) Markt und Staat in der europäischen Sozialdemokratie: Konturen einer Wirtschafts-und Sozialpolitik für das 21. Jahrhundert. In: Markt und Staat in der europäischen Sozialdemokratie Progressive Perspektiven zur Entwicklung eines sozialen und nachhaltigen Marktmodells, FES, 3-4.

[60] Crouch, C. (2011) The Strange Non-Death of Neoliberaliam. Malden, Cambridge, 47, 71-79.

[61] Judt, T. (2012) Ill Fares the Land: A Treatise on Our Present Discontents. Alexandria, Athens, 70-87, 96, 222. (In Greek)

[62] Nullmeier, F. and Kaufman F.X. (2010) Post-War Welfare State Development. In: Castles, F.G., Leibfried, S., Lewis, J., Obinger, H. and Pierson, C., Eds., The Oxford Handbook of the Welfare State, Oxford University Press, Oxford, 81-101. https://doi.org/10.1093/oxfordhb/9780199579396.003.0006

[63] Gombert, T., et al. (2009) Principles of Social Democracy. Friedrich Ebert Stiftung, Academy for social democracy, Bonn, 12-13. (In Greek) http://library.fes.de/pdf-files/bueros/zypern/10616.pdf

[64] White, S. (2010) Ethics. In: Castles, F.G., Leibfried, S., Lewis, J., Obinger, H. and Pierson, C., Eds., The Oxford Handbook of the Welfare State, Oxford University Press, Oxford, 19-31. https://doi.org/10.1093/oxfordhb/9780199579396.003.0002

[65] Rosanvallon, P. (1981) La crise de l'Etat-providence. Editions du Seuil, Paris, 57.

[66] Judt, T. (2008) Reappraisals: Reflections on the Forgotten Twentieth Century. The Penguin Press, New York, 225-228. (In Greek)

[67] Hayek, F.A. (1971) Die Verfassung der Freiheit. Tübingen.

[68] Merkel, W. (2001) Soziale Gerechtigkeit als Orientierung sozial-demokratischer Politik für das 21. Jahrhundert. In: Friedrich-Ebert-Stiftung Akademie der Politischen Bildung. Die Bedeutung der Grundwerte für politische Reformprojekte in der Wissensgesellschaft, Bonn, 49-56.

[69] Rawls, J. (2001) Theory of Justice. Polis, Athens, 355. (In Greek)

[70] Walzer, M. (1998) Education, Democratic Citizenship, and Multiculturalism. In: Weiner, E., Ed., The Handbook of Interethnic Coexistence, Continuum Publishing, New York, 7-10, 208-210.

[71] Oreopoulos, P., Von Wachter, T. and Heisz, A. (2008) The Short and Long-Term Career Effects of Graduation in a Recession: Hysterisis and Heterogeneity in the Market for College Graduates. IZA Discussion Paper, No. 3578 Bonn, 2-5.

[72] Mroz, T.A. and Savage, T.H. (2006) The Long-Term Effects of Youth Unemployment. Journal of Human Resources, 41, 259-293.

[73] Bell, D.N.F. and Blanchflower, D.G. (2009) What Should Be Done about Rising Unemployment in the UK. IZA Discussion Paper, No. 4040, Bonn, 1-2.

[74] Sen, A. (1997) Inequality, Unemployment and Contemporary Europe. International Labour Review, 136, 160-164. 
[75] Wilkinson, R. and Pickett, A.K. (2005) The Spirit Level. Why Greater Equality Makes Societies Stronger? Bloomsbury Press, New York-London-Berlin-Sydney, ix-x.

[76] Titmuss, R.M. (1974) Social Policy: An Introduction. Allen \& Unwin, London, 33-38.

[77] Fondeville, N. (2014) Scarring Effects of the Crisis. Research Note 06/2014, European Commission. Directorate-General for Employment, Social Affairs and Inclusion Directorate A-Analysis, Evaluation, External Relations. Unit A.2-Social analysis, 7, 18-19.

[78] Zoumboulakis, M. (2014) Economic Policy in the Crisis Era. 9. (In Greek)

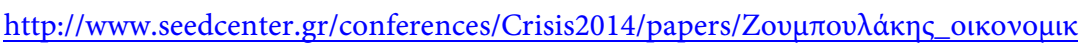

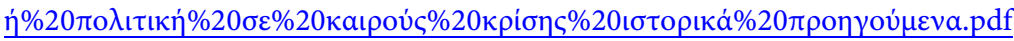

[79] Porter, M.E., Stern, S. and Green, M. (2017) Social Progress Index. Social Progress Imperative, 5 .

[80] Kossek, E., Lewis, S. and Hammer, L. (2010) Work-Life Initiatives and Organizational Change: Overcoming Mixed Messages to Move from the Margin to the Mainstream. Human Relations, 63, 3-19. https://doi.org/10.1177/0018726709352385

[81] Leighton, D. and Gregory, T. (2011) Reinventing the Workplace. Demos, London.

[82] Berman, S. (2006) The Primacy of Politics. Cambridge University Press, Cambridge, New York, Melbourne, Madrid, Cape Town, Singapore, São Paulo, 218. https://doi.org/10.1017/CBO9780511791109

[83] Kenworthy, L. (2014) Social Democratic America. Oxford University Press, Oxford-New York, 3.

[84] Harrington, M. (1972) Socialism: Past and Future. Bantam Books, New York, 230.

[85] Heilbronner, R. (1989) Reflections: The Triumph of Capitalism. New Yorker, 64, 98-109. 